\title{
REVISED Oligodendrocytes, BK channels and the preservation of
}

\section{myelin [version 2; peer review: 2 approved]}

Previous Title: Oligodendrocytes, BK channels and remyelination

\author{
Maddalena Rupnik1, David Baker (iD), David L. Selwood (D1) \\ ${ }^{1}$ Wolfson Insitute for Biomedical Research, University College London, London, WC1E 6BT, UK \\ ${ }^{2}$ Centre for Neuroscience and Trauma, Blizard Institute, Queen Mary University of London, London, WC1E 6BT, UK
}

V2 First published: 09 Aug 2021, 10:781

https://doi.org/10.12688/f1000research.53422.1

Latest published: 15 Nov 2021, 10:781

https://doi.org/10.12688/f1000research.53422.2

\section{Abstract}

Oligodendrocytes wrap multiple lamellae of their membrane, myelin, around axons of the central nervous system (CNS), to improve impulse conduction. Myelin synthesis is specialised and dynamic, responsive to local neuronal excitation. Subtle pathological

insults are sufficient to cause significant

neuronal metabolic impairment, so myelin preservation is necessary

to safeguard neural networks. Multiple sclerosis (MS) is the

most prevalent demyelinating disease of the CNS. In

MS, inflammatory attacks against myelin, proposed to

be autoimmune, cause myelin decay and oligodendrocyte loss,

leaving neurons vulnerable. Current therapies target

the prominent neuroinflammation but are mostly ineffective in

protecting from neurodegeneration and the progressive neurological

disability. People with MS have substantially higher levels

of extracellular glutamate, the main excitatory

neurotransmitter. This impairs cellular homeostasis to

cause excitotoxic stress. Large conductance $\mathrm{Ca}^{+}$-activated $\mathrm{K}^{+}$

channels (BK channels) could preserve myelin or allow its recovery by protecting cells from the resulting excessive excitability. This review evaluates the role of excitotoxic stress, myelination and BK channels in MS pathology, and explores the hypothesis

that BK channel activation could be a therapeutic strategy to protect oligodendrocytes from excitotoxic stress in MS. This could reduce progression of neurological disability if used in parallel to immunomodulatory therapies.

Keywords

KCNMA1, KCNMB4, big conductance Ca2+ activated K+ channel, oligodendrocytes, remyelination

\section{Open Peer Review \\ Approval Status \\ 1 \\ 2 \\ version 2 \\ (revision) \\ 15 Nov 2021 \\ version 1 \\ 09 Aug 2021

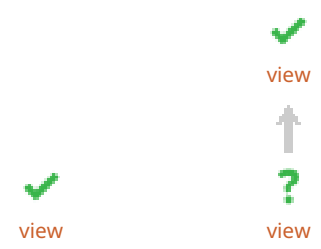 \\ 1. Enrique Balderas-Angeles $[D$, University of Utah, Salt Lake City, USA \\ Veronica Loyo-Celis, Instituto de \\ Biotecnología Universidad Nacional \\ Autónoma de México, Cuernavaca, Mexico \\ 2. Wensheng Lin ID, University of Minnesota, \\ Minneapolis, USA}

Any reports and responses or comments on the article can be found at the end of the article. 
Corresponding author: David L. Selwood (d.selwood@ucl.ac.uk)

Author roles: Rupnik M: Conceptualization, Data Curation, Formal Analysis, Methodology, Validation, Writing - Original Draft Preparation, Writing - Review \& Editing; Baker D: Conceptualization, Formal Analysis, Investigation, Validation, Visualization, Writing Original Draft Preparation, Writing - Review \& Editing; Selwood DL: Conceptualization, Data Curation, Investigation, Project Administration, Resources, Supervision, Writing - Original Draft Preparation, Writing - Review \& Editing

Competing interests: MR declares no financial interest. Patents concerning VSN16R were filed by University College London (as UCL business PLC); DS and DB are named as inventors. Through the university revenue-sharing scheme, inventors may, should the invention ever be commercialized, and in the fullness of time, receive some financial benefit.

Grant information: Funding was provided by the National Multiple Sclerosis Society (FF-1602-07939), the Wellcome Trust (092945, 206020/Z/16/Z) and the Technology Strategy Board, MRC (25036-166159).

The funders had no role in study design, data collection and analysis, decision to publish, or preparation of the manuscript.

Copyright: (c) 2021 Rupnik M et al. This is an open access article distributed under the terms of the Creative Commons Attribution License, which permits unrestricted use, distribution, and reproduction in any medium, provided the original work is properly cited.

How to cite this article: Rupnik M, Baker D and Selwood DL. Oligodendrocytes, BK channels and the preservation of myelin [version 2; peer review: 2 approved] F1000Research 2021, 10:781 https://doi.org/10.12688/f1000research.53422.2

First published: 09 Aug 2021, 10:781 https://doi.org/10.12688/f1000research.53422.1 


\section{REVISED Amendments from Version 1}

For reviewer 1 . We added a section on the disease association with the BK channel subunits.

Reviewer 2. In response to the reviewer comments, we added additional information regarding the UPR response and its significance for remyelination approaches. We changed the title to be more reflective of the review content.

We feel that these changes have enhanced the manuscript.

Any further responses from the reviewers can be found at the end of the article

MS is the most prevalent chronic demyelinating disease which affects 2.8 million people worldwide ${ }^{1,2}$. Its increasing prevalence poses a significant socio-economic burden. The aetiology of the disease is not completely understood, but demyelination pathology predominates alongside inflammation. In demyelinating diseases, like MS, an initial local attack against myelin sheath is proposed to trigger a cascade of neuroinflammatory and degenerative pathways causing damage to oligodendrocytes, myelin, and neurons ${ }^{3}$. This impairs CNS conduction. Other less common demyelinating conditions such as Neuromyelitis optica (Devic's disease), transverse myelitis, and acute disseminated encephalomyelitis all have an inflammatory component ${ }^{4}$. Demyelinating diseases may also have a genetic cause such as adrenoleukodystrophy, which is a X-linked genetic disorder where mutation in the $A B C D 1$ gene causes a defect in the corresponding $\mathrm{ABCD} 1$ transporter protein and accumulation of very long chain fatty acids in the brain and spinal cord leading to inflammation in the white matter, cerebral demyelination and neurodegeneration ${ }^{5}$. Fragile $\mathrm{X}$ syndrome is a genetic disorder where transcriptional silencing of the FMRl gene leads to loss of the corresponding fragile $\mathrm{X}$ mental retardation protein (FMRP). FMRP acts as a RNA transcriptional regulator affecting the function of hundreds of proteins ${ }^{6}$. Demyelination is an under-recognised feature of fragile $\mathrm{X}$ syndrome $^{7}$, in model systems FMRP silencing has been found to decrease the degree of myelination ${ }^{8}$.

MS treatments can be classed as disease modifying therapies, (DMTs), to delay progression, or symptom management treatments. Current DMTs are immunomodulatory, with some specifically preventing myelin attack, notably by blocking peripheral immunity ${ }^{9}$. Despite positive outcomes for neuroinflammation, underlying pathology is still not completely targeted (Table 1). B cell directed therapies are amongst the most effective treatments; as these reflect the emerging disease understanding placing memory $\mathrm{B}$ cells at the centre of the disease mechanism ${ }^{10}$. Although disability is reduced, neurodegeneration and defects in remyelination and repair still occur. Progression to secondary progressive MS (SPMS) is often not prevented and therapies successful for relapsing remitting MS (RRMS) become ineffective ${ }^{11}$ ). With the difficulty of finding strategies to prevent neurodegeneration in general and few DMTs for SPMS, new therapeutic approaches need to target underlying demyelination, to date no remyelination strategies have proved effective ${ }^{12}$. This unmet clinical need has led to the development of some diverse approaches using both repurposed drugs and novel therapeutics. Some of the most promising ideas are listed in Table 1. It is important to consider other targets that may protect mature oligodendrocytes from demyelinating pathologies like multiple sclerosis. One promising target is the the unfolded protein response (UPR). The UPR can work to preserve cell viability during periods of endoplasmic reticulum stress, like those caused by excessive inflammation, by temporarily halting translation to allow the re- establishment of protein homeostasis.

Table 1. Summary of agents showing some promise in preserving myelin or as remyelinators.

\begin{tabular}{|c|c|c|c|}
\hline Drug: & Type: & Mechanism of Action: & Reference: \\
\hline Clemastine & First generation anti-histamine. & $\begin{array}{l}\text { Potent activity against a wide range of GPCRs including histamine, } \\
\text { muscarinic and adrenergic receptors. In the reBUILD trial the drug } \\
\text { reduced visual evoked potentials latency (VEPS). Sedating and increased } \\
\text { fatigue in the trial. }\end{array}$ & 13 \\
\hline Metformin & $\begin{array}{l}\text { Chemotherapeutic agent, } \\
\text { approved for diabetes. }\end{array}$ & $\begin{array}{l}\text { Metformin was found to reverse age-related changes, including } \\
\text { repression of the UPR enabling oligodendrocytes to respond to } \\
\text { differentiation factors. Currently in clinical trials for MS. (NCT04121468) }\end{array}$ & 14 \\
\hline Bexarotene & Approved anti-cancer agent. & $\begin{array}{l}\text { Retinoid } X \text { receptor agonist. Promotes OPC differentiation and } \\
\text { remyelination. A phase } 2 \text { a trial failed on the primary outcome measure } \\
\text { but a statistically significant effect on the magnetization transfer ratio in } \\
\text { submedial lesions. A poor side effect profile means the drug will not be } \\
\text { pursued further. }\end{array}$ & 15 \\
\hline Theophylline & $\begin{array}{l}\text { Non-selective } \\
\text { phosphodiesterase inhibitor. } \\
\text { Approved drug for respiratory } \\
\text { conditions. }\end{array}$ & $\begin{array}{l}\text { The acetylated form protein Ac-eEF1A1 interacts with and removes the } \\
\text { myelination/ remyelination transcription factor Sox10 from the nucleus. } \\
\text { Theophyline activates the deacetylase HDAC2 to deacetylate eEF1A1 } \\
\text { and restore myelination capacity. Progress to clinic is not yet reported. }\end{array}$ & 16 \\
\hline Bazedoxifene & $\begin{array}{l}\text { Third generation selective } \\
\text { estrogen receptor modulator } \\
\text { (SERM). }\end{array}$ & $\begin{array}{l}\text { Enhances differentiation and remyelination of OPCs. Acts independently } \\
\text { of its normal estrogen target. The enzyme } 3 \beta \text {-hydroxysteroid- } \Delta 8, \\
\Delta 7 \text {-isomerase was identified as the potential target. }\end{array}$ & 17 \\
\hline
\end{tabular}


Pancreatic endoplasmic reticulum kinase (PERK) is implicated in this. Increasing PERK activation in mouse models of MS protected myelin, in the presence of MS- related cytokine interferon- $\gamma^{18}$. This even improved survival of remyelinating oligodendrocytes and recovery in demyelinated lesions ${ }^{18}$. A later study indicated that the PERK protective pathway can be enhanced by nuclear factor $\kappa \mathrm{B}$ (NFKB) activation ${ }^{19}$. Oligodendrocytes were rescued only in mice with MOG- induced EAE and PERK gene deficiency, whilst healthy oligodendrocytes remained unaffected ${ }^{19}$. This might indicate this UPR signalling pathway specifically protects from inflammatory and demyelinating pathology. Studies have replicated these cytoprotective effects, but also indicated the need for targeted activation of $\mathrm{NFkB}^{19-21}$. Excessive generalised activation may worsen inflammation by dysregulating immunity and promoting autoimmune reactions, possibly leading to adverse effects $^{22}$.

Alternatively, the leukaemia inhibitory factor (LIF), of the IL-6 cytokine family, was also proposed to protect mature oligodendrocytes from demyelination. Its levels determine growth and differentiation of inflammatory cells, but also possibly neural cells. Exogenous LIF protected against demyelination in cuprizone induced mouse models of MS with knockout endogenous $\mathrm{LIF}^{23}$. Since cuprizone is toxic to oligodendrocytes but does not elicit an inflammatory response as seen in the EAE model, the authors indicated this method is directly cytoprotective ${ }^{23}$. However, some studies suggest its activation might lead to negative effects on neuroinflammation, and state limited ability to cross the BBB when administered therapeutically; although its delivery and effectiveness significantly improved when using lentiviral vectors for CNS- specific expression in murine models ${ }^{23,24}$.

Similarly, agents aimed at attenuating the inflammation were also discovered to have independent neuroprotective effects which can lead to reduced demyelination. For example repurposing the antibiotic minocycline, which is thought to enhance anti-apoptotic signalling and was combined with atorvastatin to achieve an enhanced reduction in EAE severity ${ }^{25}$. In a randomised controlled trial, taking minocycline within the first 6 months of the clinically isolated syndrome significantly decreased the risk of developing MS but not after two years, which may suggest a delaying instead of disease- modifying effect $^{26}$. The diabetic treatment metformin is known to repress the UPR via a miR-132 and PERK-eif $2 \alpha$ dependent mechanism ${ }^{27}$. The selective estrogen modulator (SERM) bazedoxifene has been shown to reduce ER stress and prevent activation of the UPR in $\beta$ cells $^{28}$. In experimental MS, in the cuprizone model, bazedoxifene promotes remyelination apparently through activation of the integrated response pathway. While the mechanism of this agent's action remains unclear it is in trials for MS (Table 1).

Finally, in the MS lesion microenvironment, the excessive inflammation and failure of energy metabolism may lead to acidosis and subsequent activation of acid sensing ion channels (ASICs), which were found upregulated in both axons and oligodendrocytes in active MS lesions ${ }^{29}$. These proton gated cation channels are activated in similar conditions of excitotoxicity as the BK channel. Amiloride or psalmotoxin-1, blocking respectively ASICs or ASIC1, protected oligodendrocytes from injury related to this acidosis, and the EAE mouse model with knockout ASIC1 had increased levels of myelin immunostaining compared to wild type ${ }^{29}$.

The aims of this review are: to explain the importance of structurally and functionally intact myelin; to address the current lack of therapies targeting neurodegeneration particularly in MS; to evaluate the role of excitotoxicity in oligodendrocyte pathology and to explore the potential for therapeutic use of large conductance $\mathrm{Ca}^{2+}$ activated $\mathrm{K}^{+}$channel activators to protect oligodendrocytes from excitotoxic stress, ultimately to preserve myelination.

\section{Oligodendrocytes and myelin in demyelinating disease}

Neuronal impulse conduction is formed by action potentials (APs). These are generated from a momentary change in the ionic gradient across the axon membrane that propagates down and is relayed to the next neuron ${ }^{30}$. Repeated and synchronised through billions of neurons, these rapidly transmit information across the body. In the CNS oligodendrocytes wrap axons with compact lamellae of their membrane myelin sheath ${ }^{31}$. The low capacitance, high lipid content of myelin propagates action potentials (APs) directly onto short unmyelinated $1-\mu \mathrm{m}$ axolemma segments, nodes of Ranvier. Voltage-gated $\mathrm{Na}^{+}$channels concentrate here to integrate a voltage difference so that APs can "skip" myelin internodes through saltatory conduction to increase velocity of impulses. The diameter of myelinated axons positively correlates with conduction velocity ${ }^{32,33}$; while myelin thickness inversely correlates with capacitance ${ }^{34}$. Therefore, myelin provides an energy saving evolutionary adaptation; also because it restricts the number of $\mathrm{Na}^{+} / \mathrm{K}^{+}$ATPases to the nodes, so it decreases the chemical energy ATP required to maintain resting potential ${ }^{31}$. By myelinating larger axons, above $\sim 2 \mu \mathrm{m}$ in diameter, myelin allows signals to be transmitted fast over a long range ${ }^{31}$.

The brain expends one-fifth of total body energy output, but myelin prevents axons from receiving metabolic support extracellularly, so healthy oligodendrocytes are indispensable for axonal support (Figure 1). Although neurons rely on their own mitochondria to synthesise ATP, these require glial glycolytic products, primarily lactate ${ }^{35}$. Neuronal death can be induced by inhibiting oligodendrocyte glycolysis or neuronal mitochondrial respiration, but not by inhibiting neuronal glycolysis or oligodendrocyte oxidative phosphorylation ${ }^{36}$. It was found that deleting the lactate transporter protein MCT1 impaired axons and caused atrophy ${ }^{37}$. MCT1 being expressed relatively specifically by oligodendrocytes, these results indicate oligodendrocytes are important for healthy neuronal metabolism. However, other studies found that upon electrical stimulation neurons used their own glucose to synthesise energy, which might indicate oligodendrocytes are a primary glycolytic source only for neurons at $\operatorname{rest}^{38}$. MCT1 is lost in neurodegenerative diseases like amyotrophic lateral sclerosis, where motor neuron death at the spinal cord indicates impaired axonal lactate supply ${ }^{37}$. Neurons may depend on 


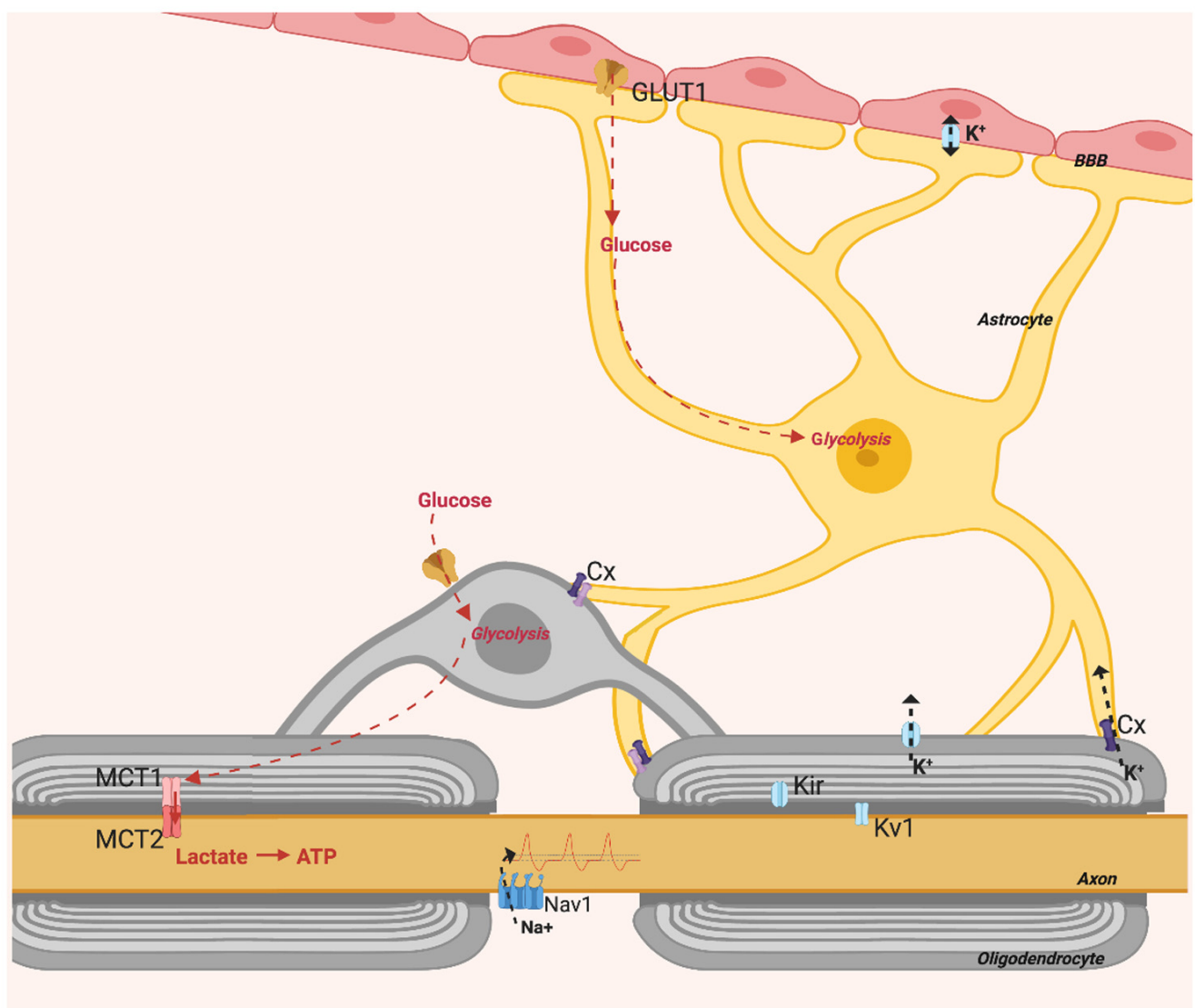

Figure 1. Oligodendrocytes provide axons with metabolic support, this is activity dependent and requires communication with astrocytes. Figure created with BioRender.

oligodendrocytes for metabolic support to survive and function properly, but the pathological relationship may cause damage before or separate to evident demyelination.

Metabolic support to axons requires astrocytes, which transfer glycolytic products to neurons through oligodendrocytes (Figure 1). This by way of connexins on astrocytic processes and on oligodendrocytes which co-localise to form gap junctions $^{39}$. Astrocytes have glycogen stores and upon hypoxia or hypoglycaemia glycogen is catabolised into lactate for delivery to neurons ${ }^{40}$. Furthermore, connexins found at paranodes may indicate a cooperation of astrocytes and oligodendrocytes in regulating axon electrical properties ${ }^{39,41}$ (Figure 1). Astrocytes not only regulate axon activity and deliver metabolites; they also regulate BBB passage with astrocytic end feet that adjust membrane permeability. Healthy myelin preserves axon structure, metabolism and function, and potentially improves the general glia-axon relationship.

\section{Demyelination in multiple sclerosis}

Demyelination is the erosion of myelin sheaths, which exposes nerve fibres leading to failure of impulse conduction. It can derive directly from traumatic or ischaemic injury ${ }^{42}$. Alternatively it originates from attack of myelin related proteins in autoimmune disease ${ }^{43}$. Loss of myelin does not necessarily lead to neuronal death, but overburdens axons by decreasing efficiency of energy homeostasis, making it harder for neurons to meet metabolic demands. Without myelin for saltatory conduction, energy needed to relay impulses increases. This eventually leads to increased functional impairment and susceptibility to further neurodegeneration.

The "sclerosis" of MS is the fibrotic lesion that forms in the brain or spinal cord from gliosis of astrocytes and microglia, often located near vasculature. The BBB appears "leaky" as shown by gadolinium-enhanced magnetic resonance imaging (MRI) from infiltration of blood-borne macrophages, $\mathrm{T}$ lymphocytes and B cells, which contribute to demyelination ${ }^{43}$ (Figure 2). After two temporally and spatially distinct acute inflammatory episodes, MS can diagnosed and is classified as relapsing-remitting or primary progressive MS depending on the disease course ${ }^{4}$. As lesions become chronic, factors determining whether inflammation resolves and remyelination occurs are not fully understood. However, demyelination may share pathways with ischaemia and viral infection ${ }^{4}$. Persisting inflammation and remyelination failure and nerve loss contribute to progressive $\mathrm{MS}^{11}$. Without tissue repair, permanent loss of function often ensues. 


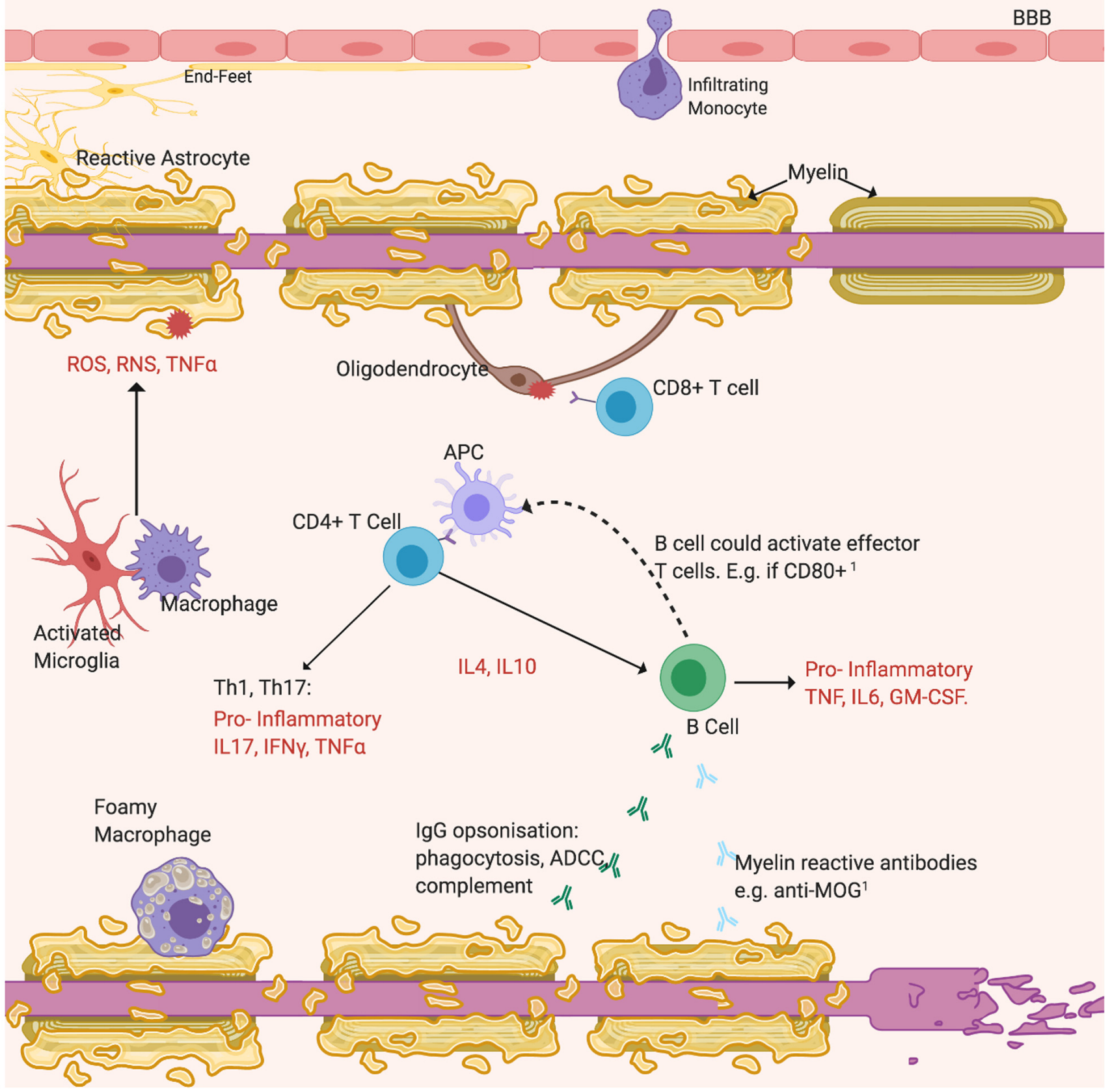

Figure 2. Demyelination may derive from antibody attack. Opsonisation by non-specific IgG activates the cytotoxic complement system and ADCC. The emerging importance of B cells is highlighted by recent findings ${ }^{44}$. Additional roles include possibly secreting antimyelin antibodies and acting as APCs to increase T cell activation 45, labelled 1. Cytotoxic CD8+ T cells react against self-antigens expressed by oligodendrocytes. Resident microglia or peripheral macrophages phagocytose myelin residues and debris. Reactive astrocytes, activated microglia and Th cells activated by APCs drive inflammation by secreting pro-inflammatory cytokines (TNFa, IFNy, interleukins) and neurotoxicity by releasing free radicals (ROS, RNS) ${ }^{43}$. Subsequently to myelin loss, axons degenerate. Figure created with BioRender.

Episodes may resolve incompletely and RRMS invariably involves neurological decline. Motor symptoms generally affect all patients eventually during disease course, but can involve sensory system particularly sight, pyramidal tracts, psychological aspects, brainstem and autonomic functions ${ }^{46}$. Spinal cord lesions typically cause most of the lower limb disability and are both the white and grey matter ${ }^{47}$, which contribute to the atrophy observed. This is observed early in MS brain and spinal cord when measured by atrophy using MRI, as an indicator of neurodegeneration ${ }^{48}$. Associated neuroaxonal damage, measured as serum and notably intrathecal neurofilament, correlates with disability severity ${ }^{49}$. Most patients eventually proceed to SPMS, notably those with significant early disease activity ${ }^{4}$. SPMS develops when compensation 
pathways becomes exhausted and is notably associated with neurodegenerative state with progressive atrophy, enlarging lesions, chronic inflammation and remyelination failure.

\section{Preserving myelin}

Oligodendrocytes are limited in their ability to respond to damage and at least in part depend on replacement by their precursors, $\mathrm{OPCs}^{50}$. In the adult $\mathrm{CNS}, \mathrm{NG}^{+}$cells, which include OPCs and neural progenitors, constitute nearly $9 \%$ of white matter. Their migration into sites of injury is crucial for remyelination, whereby myelin regenerates spontaneously around demyelinated axons ${ }^{51}$. Preserving myelin is important because neuroaxonal regeneration is limited. Macrophages have a strong influence, and microglia promote this by clearing myelin debris ${ }^{52}$. Underlying demyelination and inflammation must resolve before new myelin forms. Remyelination may protect axons from inflammation-mediated neurotoxicity ${ }^{53}$ and is observed in both acute and chronic lesions, even concomitant to demyelination, and in early $\mathrm{MS}^{43}$.

Successful remyelination depends on sufficient OPC pools, their migration and survival, until differentiated into myelinating oligodendrocytes; but this does not guarantee it. In MS, OPCs differentiation may arrest before myelin synthesis completes $^{42}$. Axonal density is higher in remyelinated than chronic demyelinated plaques. However, demyelination may re-occur more frequently in new myelin because newly differentiated oligodendrocytes may produce thinner and shorter sheaths, possibly from external ischaemic factors of the neuroinflammatory environment impairing proper myelination ${ }^{54}$. Additionally, lesion remyelination occurs $20 \%$ more often in acute than chronic lesions, so remyelination may inversely correlate with disease progression or age ${ }^{55}$. Therefore, preserving myelin might provide a better neuroprotective strategy than remyelination.

\section{Communication between axons and myelin}

About one-third of myelin sheath constitutes proteins that determine myelin architecture. Myelin basic protein (MBP) is a final component added to sheaths, responsible for compaction. MBP localises and draws two adjacent membranes together at clusters, where it forms a dense fibrillary network ${ }^{56}$. This prevents signal dissipation and makes neurons more energy efficient. Downregulation of MBP impairs sheath structure in vivo and knockout decreases axonal calibre ${ }^{57,58}$. Conversely, 2',3'-Cyclic nucleotide 3'-phosphodiesterase (CNP) regulates cytoplasm quantity within myelin by maintaining actin cytoskeleton. This creates channels and directly counteracts MBP compaction ${ }^{59}$. Working antagonistically, CNP and MBP can adjust these channel systems, possibly to modulate the type and amount of substrate exchange with axons. In mice, knockout of $C N P 1$ and of the functionally similar myelin proteolipid protein caused loss of fibres, of axonal integrity and axonal swelling by impairing neuronal transport ${ }^{58,60}$. This indicates that intact microstructure is important to preserve local support by oligodendrocytes and that effective conduction depends on this. Indeed, these properties of myelin microstructure can vary to preserve diverse neural networks, to adjust input latencies in nuclei. A latency of about $2 \mathrm{~ms}$ remains constant for thalamocortical signals to reach the sensory cortex despite fibres of different lengths ${ }^{61}$. Instead of gross insulation, myelin tunes its microstructure to local axon requirements.

Electrically-silenced axons myelinate inadequately ${ }^{62}$. Maintaining high $\mathrm{K}^{+}$levels extracellularly reduced myelination by increasing depolarisation duration, so APs are a putative channel of communication with oligodendrocytes ${ }^{63}$. Recent advances in electron microscopy and myelin preservation revealed structure of the developed myelin sheath around axons ${ }^{64}$. It is now possible to infer a peri-axonal space, where APs may be relayed by neurotransmitter release. Glutamate is the main excitatory neurotransmitter of the nervous system. Typically, it is released at axon terminals to bind to ligand gated ionotropic receptors found post-synaptically on dendrites. Types of ionotropic receptors are glutamatergic NMDARs, AMPARs and kainate receptors. Upon neurotransmitter binding these open voltage-gated channels for selective cation influx, for AP relay ${ }^{65}$. In mature oligodendrocytes, glutamate may be released at the axolemma to affect the inner tongue of myelin sheath.

Glutamate release from synaptic vesicles along axons can stimulate MBP production to promote the insulating properties of myelin ${ }^{66}$. Glutamatergic synapses are a feature of developing OPCs, whereby differentiating oligodendrocytes may depend on glutamate signalling for myelination ${ }^{67}$. Activity dependent myelination may promote the migration and differentiation of OPCs. Stimulating the premotor cortex resulted in increased OPC migration and myelin thickness only in the optogenetically stimulated mouse model. This was associated with improved motor skills ${ }^{68}$. Glutamatergic signalling downregulation may alter myelin thickness because, in mice, reduction of visual stimuli associated with reduced conduction velocity ${ }^{69}$. When tetanus toxin was used to inhibit glutamate release from the synaptosome, $\mathrm{Ca}^{2+}$ influx into oligodendrocytes did not occur ${ }^{70}$, supporting mediation by excitatory neurotransmitter release. Although most myelinic ionotropic receptors are removed with differentiation, their use in preserving correct myelination in mature oligodendrocytes might explain the few remaining ${ }^{70}$. NMDARs at the myelin sheath also gauge glycolytic delivery in response to axon energy demand ${ }^{71}$. Substrate exchange may be triggered by AMPAR/ NMDAR activation, which induced exosome delivery ${ }^{72}$. Dysregulation of firing frequency would therefore reduce myelinic neuronal support (Figure 1). In pathology this activity dependent alteration of myelin architecture may be rendered unresponsive, counterproductive or even toxic to neurons, even before overt demyelination. Modulating this glutamatergic signalling may preserve myelin and neurons.

\section{Excitotoxic stress}

\section{Excessive extracellular glutamate}

Excitotoxic stress is caused by excessive or prolonged activation of glutamatergic receptors causing $\mathrm{Ca}^{2+}$ overload. This sustains pro-apoptotic pathways involving enzymes and transcription factors like MAPK and NF- $\kappa B$, which degrade membranes, proteins and intracellular organelles. Increased glutamatergic signalling can be triggered by the energy deficiency from the cellular damage in lesions, mitochondrial 
dysfunction and oxidative stress ${ }^{73,74}$. The last involves highly reactive and damaging free radicals: ROS and RNS. These cause mitochondrial membrane damage by lipid peroxidation, which exacerbates cellular burden and glutamatergic signalling ${ }^{75}$. At high levels glutamate is thought to induce oxidative stress by means of blockade of the glutamate/cystine antiporter (XC-Cys/Glu) that prevents uptake of cystine and synthesis of the anti-oxidant glutathione, in a form of cell death termed ferroptosis or oxytosis ${ }^{76}$.

Damage to neurons causes axon swelling, where ion channels including voltage-gated sodium channels are upregulated to attempt compensation for impaired conduction ${ }^{77,78}$. Excitotoxic damage to myelin may cause this upregulation without necessarily causing overt demyelination ${ }^{78}$. Axon swelling impairs network connectivity in MS, where sustained glutamatergic activation associates significantly with increased neurological disability ${ }^{79}$.

Glutamate is upregulated in MS CSF $(\mathrm{p}<0.001)$ and carrying the polymorphism rs794185 that further increases this associates with neurodegeneration ${ }^{79,80}$. The major source of glutamate production is difficult to discern, but evidence suggests neuroinflammation is important. Pro-inflammatory cytokines TNF $\alpha$ and IL-1 $\beta$ cause neurotoxicity by downregulating astrocytic glutamate transporter and glutaminase which accumulates glutamate in the extracellular space s $^{73,81,82}$. IL-1 $\beta$ but not $\mathrm{TNF} \alpha$ are established as significantly upregulated in
MS $\mathrm{CSF}^{82,83}$. Immune activation upregulated the cystine glutamate exchanger on macrophages and microglia and in MS patients $^{84}$. To synthesise important antioxidant glutathione this exchanger releases glutamate extracellularly.

Table 2 describes drugs targeting excitotoxicity in MS, highlighting the still unmet clinical need. These therapies are inadequate clinically because antagonists of glutamatergic pathways can downregulate excitatory CNS conduction, which importantly can cause serious adverse events. Selectivity could be improved by targeting receptor subunits specific to glial cells and that are more permeable to pathological $\mathrm{Ca}^{2+}$ accumulation, like NR1 and NR3 NMDAR subunits ${ }^{85}$. Sodium channel blockers provide an alternative means to control excitotoxicity and some benefit has been noted in the more recent clinical trials, but they are poorly tolerated leading to non-compliance ${ }^{86,87}$.

\section{Oligodendrocytes are deficient in their response to excitotoxic stress}

Oxidative damage to proteins and lipids is substantially increased in acute demyelinating lesions compared to healthy white matter. Hypertrophic astrocytes and foamy macrophages are able to limit this damage by upregulating antioxidant superoxide dismutase, but not other components of lesion tissue including neurons and oligodendrocytes ${ }^{88}$. Oligodendrocytes have a particularly inefficient antioxidant protection. These have a reduced ability to synthesise glutathione ${ }^{89}$ and

Table 2. List of completed clinical trials to lower excitotoxicity and investigate neuroprotection in MS.

\begin{tabular}{|c|c|c|c|c|}
\hline Drug: & Action: & $\begin{array}{l}\text { Primary } \\
\text { Outcome: }\end{array}$ & Results: & $\begin{array}{l}\text { Study } \\
\text { Reference: }\end{array}$ \\
\hline Memantine & NMDAR antagonist. & $\begin{array}{l}\text { Cognitive } \\
\text { Impairment. }\end{array}$ & $\begin{array}{l}\text { Stopped due to worsening } \\
\text { neurological deficits. }\end{array}$ & 90 \\
\hline Riluzole & $\begin{array}{l}\text { Inhibits glutamate release from synaptic } \\
\text { terminals; NMDA and kainate receptors } \\
\text { modulator; keeps VGCCs inactivated. }\end{array}$ & Brain atrophy. & $\begin{array}{l}\text { No significant difference compared to } \\
\text { placebo }(p=0.065) \text {. }\end{array}$ & 91 \\
\hline Memantine & NMDAR antagonist. & Spasticity. & No significant difference $(p=0.65)$. & 92 \\
\hline Amantadine & NMDAR antagonist. & Fatigue. & $\begin{array}{l}\text { Reduced compared with placebo } \\
(p<0.05) \text {. }\end{array}$ & 93 \\
\hline $\begin{array}{l}\text { Amiloride, Riluzole, } \\
\text { Fluoxetine }\end{array}$ & $\begin{array}{l}\text { Respectively: reduce pro-apoptotic } \\
\text { axonal } \mathrm{Ca}^{2+} \text { overload; glutamate } \\
\text { mediated excitotoxicity; increases } \\
\text { astrocytic lactate release to support } \\
\text { neuronal energy metabolism. }\end{array}$ & Brain atrophy. & No significant difference $(p=0.99)$. & 94 \\
\hline Lamotrigine & Sodium channel blocker & $\begin{array}{l}\text { Cerebral volume } \\
\text { loss. }\end{array}$ & $\begin{array}{l}\text { At } 24 \text { months, no significant } \\
\text { reduction in cerebral volume loss with } \\
\text { lamotrigine compared with placebo. }\end{array}$ & 86 \\
\hline Phenytoin & Sodium channel blocker & $\begin{array}{l}\text { Thickness of } \\
\text { retinal nerve } \\
\text { fibre layer. }\end{array}$ & $\begin{array}{l}\text { A } 30 \% \text { reduction in the extent of } \\
\text { retinal nerve fibre layer loss with } \\
\text { phenytoin at } 6 \text { months compared with } \\
\text { placebo. }\end{array}$ & 95 \\
\hline Oxcarbazepine & Sodium channel blocker & $\begin{array}{l}\text { CSF NFL } \\
\text { reduction. }\end{array}$ & $\begin{array}{l}\text { Oxcarbazepine had no significant } \\
\text { effect on CSF NFL levels, an effect on } \\
\text { EDSS and MSWS scores was noted. }\end{array}$ & 96 \\
\hline
\end{tabular}


their death positively correlates with concentration of the highly reactive lipid peroxidation product $4-\mathrm{HNE}^{97}$. Oligodendrocytes are also the main cells that store iron in a balance that is susceptible to conversion to its oxidative divalent form ${ }^{98}$. Their susceptibility to excess glutamate activation specifically is supported by in vitro studies. Only upon inhibition of glutamatergic receptors in oligodendrocytes-only cultures were the apoptotic indicators DNA fragmentation and caspase-3 abolished $^{82,99}$.

Experimental autoimmune encephalomyelitis (EAE) is an established MS model induced by adoptive transfer of anti-myelin protein $\mathrm{T}$ cells. In EAE mice, $60 \%$ more of the oligodendrocytes population was preserved with the AMPA/kainate receptor inhibitor NBQX compared with administering phosphate buffered saline (PBS) only, which also improved neurologic impairment score $(\mathrm{p}<0.01)^{100}$. AMPAR-mediated $\mathrm{Ca}^{2+}$ influx activates a sustained phosphorylation of ERK1/2 to activate proapoptotic pathways in oligodendrocytes and mitochondrial impairment in a manner similar to ischaemia ${ }^{74}$. $\mathrm{Ca}^{2+}$-permeable AMPARs are upregulated only at MS lesions, but not in regions of healthy tissue ${ }^{101}$, so $\mathrm{Ca}^{2+}$ permeability might indicate upregulation of excitotoxic responses with demyelination. Considering the complex pathological microenvironment of lesions, glutamatergic receptor inhibition alone might not prevent cytotoxicity locally in MS. Pro-inflammatory damage spreads centrifugally from the lesion centre ${ }^{4}$, so inhibition might instead prevent spread of excitotoxins.

AMPAR/kainate receptors are mainly expressed on oligodendrocytes soma, while myelin mainly expresses NMDARs $^{102}$. Excitotoxic stress to myelin can cause decompaction of myelin sheath ${ }^{103}$, which can impair neuronal metabolism before overt demyelination. Since damaged or degraded myelin sheaths increase neuronal metabolic burden and expose axons to inflammation related toxins, this suggests therapeutically protecting myelin from excitotoxic stress may be neuroprotective in MS. A characteristic feature of MS is a dying back oligodendrogliopathy which, in a similar way to complement activation by direct antibody attack $^{4}$, might also be caused by activation of catalases and mitochondrial redox damage at myelin processes which retrogradely affects oligodendrocytes.

NMDARs induce weaker $\mathrm{Ca}^{2+}$ currents compared with AMPARs but sustain these for longer ${ }^{65}$. The small cytosolic compartment of myelin may quickly accumulate $\mathrm{Ca}^{2+}$ concentrations sufficiently high to be toxic. All compartments needed for NMDARs to be functional have been detected with immunoblotting: NR1, NR2 and NR3 ${ }^{102}$. These require activation by both glutamate and its co-agonist glycine. Release of only glutamate from myelinated axolemmas has been established ${ }^{70}$. The $\mathrm{Mg}^{2+}$ block characteristic of NMDARs can be released by a slight depolarisation ${ }^{65}$, which may justify the expression of AMPARs on myelin at lower concentrations. Especially because AMPARs inhibitors only partially abolished the $\mathrm{Ca}^{2+}$ current through myelin, but completely at oligodendrocytes soma, while non-selective ionotropic receptor inhibitor completely abolished at both locations ${ }^{102}$. This suggests a mediating effect by AMPAR.

However, no significant decrease of NMDAR mediated $\mathrm{Ca}^{2+}$ into oligodendrocytes when their inhibitors, NBQX or D-AP5 respectively, were added after ischaemia ${ }^{103}$. The authors proposed excitotoxicity does not derive directly from glutamatergic $\mathrm{Ca}^{2+}$ influx, but from the resulting $\mathrm{K}^{+}$and $\mathrm{H}^{+}$increase because the NMDA evoked current correlated with $\mathrm{K}^{+}$ increase. The resulting decrease in $\mathrm{pH}$ (from $\mathrm{K}^{+}$and from the hypoxic cell) might activate $\mathrm{H}^{+}$-gated TRP channels which then caused about $70 \%$ of the $\mathrm{Ca}^{2+}$ rise ${ }^{103}$. TRP block reduced myelin decompaction, so it is possible these channels are more responsible for the ischaemic excitotoxicity to oligodendrocytes than direct ionotropic receptor activation. Alternatively, the majority of $\mathrm{Ca}^{2+}$ may derive from a secondary source, such as from subsequently activated voltage gated calcium channels (VGCCs) or the reversal of the $\mathrm{Na}^{+} / \mathrm{Ca}^{2+}$ exchanger which can occur in conditions of excessive depolarisation $^{101}$.

Dying oligodendrocytes release high levels of $\mathrm{Fe}^{2+}$ which directly contributes to oxidative injury to neurons ${ }^{98}$. This accumulates at acute demyelinating lesions, phagocytosed and released through oxidative burst. Ferrous iron, $\mathrm{Fe}^{2+}$, is a mediator of the Fenton reaction that synthesises hydroxyl and $\mathrm{H}_{2} \mathrm{O}_{2}$ radicals $^{98}$. Excitotoxic stress will damage oligodendrocytes, which will in turn release more oxidative stress, although contribution of oligodendrocytes excitotoxicity is still unclear because complex to quantify.

\section{BK channels reduce excitotoxic stress}

\section{BK channels}

Large conductance calcium-activated, voltage gated potassium channels (BK channels) are the most diverse within the family of transmembrane protein channels, which also includes small and intermediate $\mathrm{K}^{+}$conductance ( $\mathrm{SK}$ and $\mathrm{IK}$ ) channels ${ }^{104}$. These are activated by thresholds of voltage or $\mathrm{Ca}^{2+}$ transients and accordingly control membrane potential by mediating efflux of the required amount of hyper-polarising $\mathrm{K}^{+105}$. They can also be activated by other metal ions such as $\mathrm{Mg}^{2+}$, but also by $\mathrm{pH}$, arachidonic acid and nitric oxide. Encoded by the KCNMA1 (or SLO) gene, BK channels constitute a heterodimer of pore-forming $\alpha$-subunits and a monomer comprising a voltage-sensing and a calcium-sensing module ${ }^{106}$. Ubiquitous, $\mathrm{BK}$ channels are overexpressed in regions of high $\mathrm{Ca}^{2+}$ concentrations ${ }^{107}$. By mediating $\mathrm{K}^{+}$ transients out of cells, BK channels can also regulate $\mathrm{K}^{+}$ homeostasis, cell volume, and therefore have various functions including neuronal excitability, smooth muscle relaxation, blood pressure control and electrical tuning of cochlear hair cells ${ }^{108}$

The highly dynamic physiological properties of BK channels are partly due to the numerous $\alpha$-subunit splice variants, which makes their translated protein structure highly versatile physiologically. For example, a cysteine-rich 59-amino-acid insert between RCK domains called STREX variant can be added to the $\mathrm{C}$-terminus ${ }^{109}$, resulting in increased sensitivity 
to activation, inducing higher neuronal firing frequencies. Additionally, BK channels assemble auxiliary subunits, such as $\beta$ subunits $(\beta 1-4)^{110}$. These can modify activity, including modifying sensitivity to its activators, voltage or $\mathrm{Ca}^{2+}$, or by activating protein kinases ${ }^{111}$. Furthermore, the association with $\gamma$ subunits, which are leucine rich repeat containing proteins, can increase stimulability of the BK channel by decreasing the negative voltage difference threshold ${ }^{112}$. Ultimately, this increases the range of pharmacological applications of these channels.

\section{BK channels regulate neuronal excitability}

In the CNS, BK channels are abundantly expressed on axons, dendrites, soma and synaptic terminals in widespread CNS regions. Here, these can control the fast phase of after-hyperpolarisation. Additionally, these can control AP output by changing the magnitude and duration of incoming $\mathrm{Ca}^{2+}$ spikes at dendrites ${ }^{113}$. This will determine AP duration and firing frequency ${ }^{114}$. BK channels can mediate their activities and their responses specifically for their cellular location and type of neuronal cell by co-localising with functionally distinct $\mathrm{VGCCs}^{114}$. BK channels have been shown to co-localise with L-/, P/Q-, or N-/ types of $\mathrm{VGCCs}^{115,116}$. Depending on the frequency of basal firing, the BK channels at that neuronal cell will typically provide the opposite effect to modulate and re-set the phase, ultimately to flatten the frequency-current curve and control neuronal excitability. This would occur in a manner similar to hyperpolarisation activated by cyclic nucleotide gated channels, that set the "pacemaker" firing frequency in the brain ${ }^{117}$. Overall, studies of BK channels indicate these tune the neuronal signal by amplifying it if weak or reducing it if too strong, rather than stringently enhance inhibition or excitation ${ }^{118-120}$.

BK channels also have an important role in directly mediating neurotransmitter release, this is supported by their co-localisation to VGCCs with those of the P/Q-type being most frequently observed. This co-localisation occurs predominantly at dendrites where it regulates dendritic spike generation relative to neurotransmitter release ${ }^{121}$. This is consistent with localisation of the BK $\alpha$ subunits at presynaptic terminals in functionally important axon tracts ${ }^{122}$. At these locations, BK channels limited the $\mathrm{Ca}^{2+}$ mediated neurotransmitter release by decreasing presynaptic APs duration ${ }^{122}$. Indeed, release of neurotransmitter from vesicles is triggered by $\mathrm{Ca}^{2+}$ elevated locally through VGCCs, once the propagated AP reaches the terminal ${ }^{123}$. Typically, BK channels would reduce neurotransmitter release, because these are able to reduce the amplitude of the presynaptic AP. An important demonstration of this is the effect on neurotransmitter release by CA3 hippocampal neurons and associated APs upon addition of BK channel blockers. The resulting spontaneous EPSCs increased in amplitude and frequency ${ }^{122}$. This inhibition ultimately reduces release of glutamate, but does not occur for inhibitory neurotransmitter $\mathrm{GABA}^{124}$. Therefore, BK channels are key to avert overexcitation of the post synaptic neuron.

\section{Mediators of excitotoxic stress}

Physiologically, BK channels can prevent too much neurotransmitter from causing excessive depolarisation and $\mathrm{Ca}^{2+}$ accumulation post-synaptically. In mice where acute focal cerebral ischemia was induced by middle cerebral artery occlusion, the neurological symptoms were significantly higher with knockout of the BK $\alpha$ subunit compared to wild type ${ }^{125}$. This may imply glutamate-induced oxidative stress, and consequences for acute and chronic neurodegeneration. This negative feedback by BK channels might only occur if propagated APs are high enough to induce levels of intracellular $\mathrm{Ca}^{2+}$ and neurotransmitter similar to those observed in pathological conditions. For example, only upon addition of 4-AP, a non-specific inhibitor of voltage gated $\mathrm{K}^{+}$channels, were BK channels activated to decrease AP amplitude post-synaptically and decrease neurotransmitter release ${ }^{126}$. No amplified repolarisation or reduced neurotransmitter release by BK channels was observed without 4-AP. This is specific to excitatory neurotransmitter release, because a concentration dependent reduction in ischaemia mediated by NMDAR correlated with increased opening of BK channels by the activator NS1619 ${ }^{127}$. By creating a negative feedback control to disproportionate neurotransmitter release, BK channels may be an emergency break to prevent hyperexcitability and subsequent toxicity.

Based on the reviewed evidence, there is an association of BK channel subunits with disease. BK channel activation is neuroprotective in animal models of spinal cord injury, ischaemia and excitotoxic stress ${ }^{45,125,127,128}$, which share some pathological similarities with MS. This is confirmed by allele knockout or blockage with the antagonists iberiotoxin and/or paxilline that exacerbated injury ${ }^{125,127}$. The agonist isopimaric acid targeted the $\alpha$ subunit to improve motor function in rats with spinal cord injury ${ }^{45}$. Similarly, NS1619 activated subunit $\alpha 1$ to effectively increase neuroprotection in rat and mouse cortex when used with leptin ${ }^{127}$. Certain subunits may only be activated and therefore effectively targeted in the presence of cellular injury or excitotoxic conditions ${ }^{126,128}$, a quality which could arguably improve specificity of an agent to injured tissue. However, these studies focused on neuron expression of BK channels and axon rather than oligodendrocyte integrity as outcome. In clinical trials, BMS-204352 activates KCNMA1, but also activates another potassium channel KCNQ. This was trialled as a safer neuroprotective agent to reduce intracellular $\mathrm{Ca} 2+$ levels in acute ischaemic stroke, but did not significantly improve outcome in this study ${ }^{129}$. Andolast has been shown to significantly improve asthma symptoms compared to placebo, but its subunit targets have not yet been investigated ${ }^{130}$. The anti- glaucoma agent unoprostone isopropyl activated iberiotoxin resistant $\mathrm{BK}$ channels, therefore likely successfully targeted the $\beta 2$, or $\beta 3$, subunits ${ }^{131}$. The $\beta$ regulatory subunit is generally quite tissue specific and therefore arguably a better target for an agonist than the $\alpha$ - subunit $^{132}$. In the CNS, KCNMB4 and KCNMB2 are the main regulatory subunits expressed ${ }^{133}$. VSN16R, which is thought to target preferentially the $\beta 4$ subunit, has shown promise in reducing spasticity at higher doses with few side effects $^{133,134}$. Notably, KCNMB4 is expressed in human mature oligodendrocytes (Figure 3) and is possibly more abundant in chronic inactive MS lesions ${ }^{135}$. Evidence is needed to ascertain whether an agonist to KCNMB4, or to another regulatory subunit, changes outcome in MS pathogenesis by 

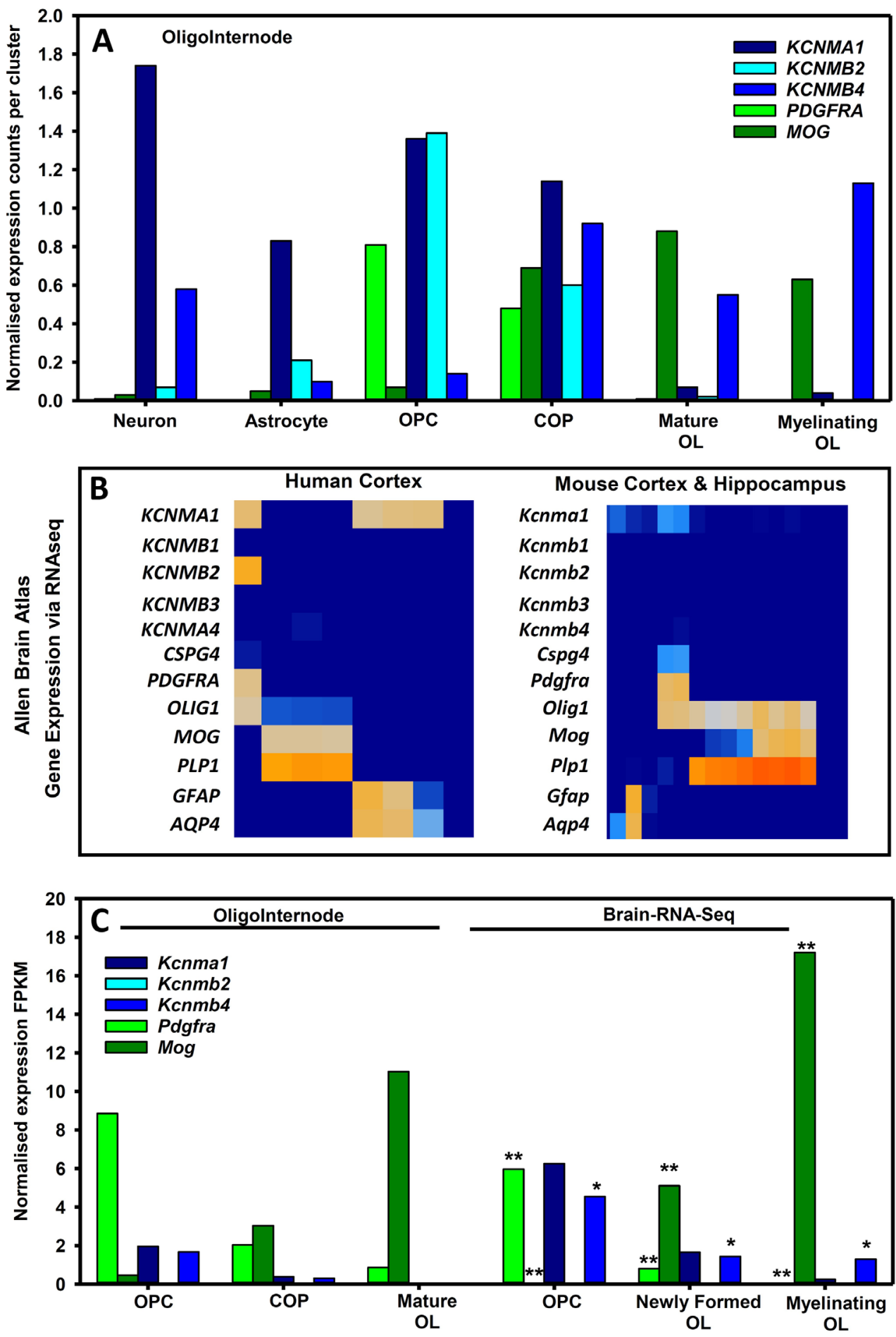

Figure 3. Oligodendrocyte expression of BKCa channels in humans and mice. The expression of: BK channels; platelet-derived growth factor receptor alpha (PDGFRA) and chondroitin sulphate proteoglycan four (CSPG4/NG2) as markers for oligodendrocyte precursor cells (OPC) and committed oligodendrocyte precursors ((COP); myelin oligodendrocyte glycoprotein (MOG) and proteolipid protein one (PLP1) as markers of mature oliogdendrocytes (OL); human glutamatergic neurons (Neuro2 GAD2 0.02, SLC17A7 2.11 (Jäkel et al. 2019 ); and aquaporin 4 (AQP4) and glial fibrillary acidic protein (GFAP) as markers for astrocytes channels was extracted from public data bases (A) Expression of BK channels in human cells in human white matter tissues extracted from the oligointernode (https://ki.se/en/mbb/ oligointernode ${ }^{135}$. (B) Expression of human and mouse BK channels from cortical brain tissue using 10X single cell RNAseq from the Allen Brain Atlas (www.portal.brain-map.org) (C) BK expression in OPC and mature oligodendrocytes from RNAseq data from the Oligointernode portal ${ }^{136}$ and the Brain RNA-Seq portal (www.brainrnaseq.org ${ }^{137}$ ). Data is expressed as fragments per kilobase of transcript per million mapped reads $($ FPKM). * = data values reduced 10 times ** = data values reduced 100 times. 
targeting oligodendrocytes and by preserving myelin. Recently Fragile $\mathrm{X}$ syndrome the major genetic cause of intellectual disability has been shown to have a demyelinating component. BK channel activation (specifically $\alpha 1 \beta 4$ ) has been shown to restore both electrophysiological and behavioural functions in experimental Fragile X.

\section{Activating BK channels to protect oligodendrocytes}

Much of the available evidence relates to neurons, but if there is a functional link between the role of BK channels and oligodendrocytes in mediating this excitotoxic stress, targeting this could possibly provide an avenue for disease modifying therapy in MS.

Although BK channels, notably KCNMB4 isoforms are neuronally expressed ${ }^{138}$, it is evident that KCNMB4 is also present and differentially expressed by oligodendrocytes ${ }^{135,139}$. OPCs were associated with high expression of KCNMAl and $K C N M B 2$ (Figure 3A. 3B), at a time when they express many ion channels perhaps as part of the pre-myelination glial-neuronal synapse $^{140}$. However, it is evident that oligodendrocyte maturation and myelination was associated with their relative loss and the upregulation of the KCNMB4 BK isoform (Figure 3A, 3B). In addition transcriptomic expression of KCNMA1 and KCNMB4 in NG2+ cells has been found ${ }^{141}$.

Human KCNMB4 expression increases as OPCs mature into oligodendrocytes and was increased in myelinating oligodendrocytes (Figure 3A). This is perhaps consistent with elevated KCNMB4 expression in chronic inactive multiple sclerosis lesions ${ }^{135}$. In contrast mouse OPC and oligodendrocytes do not seem to express much Kcnmb2 (Figure 3B, 3C). However, as occurs in humans, Kcnmal is most marked in the OPC and is down-regulated as oligodendrocytes mature and myelinate (Figure 3C). Likewise, Kcnmb4 can sometimes be found at higher levels in OPCs, but persists in mature oligodendrocytes to be the dominant $\mathrm{BK}$ channel isoform (Figure 3B, 3C). Kcnmb4 is expressed on the cell membrane and is also expressed in mitochondria ${ }^{132}$. Loss of Kcnmal message during development is consistent with protein expression and functional calcium-induced signalling activity ${ }^{139}$ and may play a role in oligodendrocyte differentiation.

Additionally, electrophysiological recordings of increased oligodendrocytes depolarisation corresponded to the increased intracellular fluorescence from labelled $\mathrm{Ca}^{2+}$ upon glutamate-induced stimulation; which occurred only when the BK channel blocker iberiotoxin was $\operatorname{added}^{139}$. This suggests a role of $\mathrm{BK}$ channels to regulate $\mathrm{Ca}^{2+}$ influx to protect oligodendrocytes from excitotoxic stress. Other evidence indirectly supports this. As such the fundamental subunits of the NMDARs, NR1, NR2 and NR3 co-localise with myelin protein from primary optic nerve oligodendrocytes upon immunohistochemical staining ${ }^{102}$. Blocking NMDARs substantially blocked myelin damage upon chemically induced ischaemia in vitro ${ }^{102}$. This was the first evidence of axo-myelinic signalling, indicating that glutamate released from the axon can cause $\mathrm{Ca}^{2+}$ to enter oligodendrocytes through the myelin sheath. Importantly, it has been found that mature oligodendrocytes express NMDARs, and that small quantities of excitatory neurotransmitters diffusing between axon and myelin could form sufficiently high concentrations to give rise to large $\mathrm{Ca}^{2+}$ transients within mature oligodendrocytes ${ }^{142}$. In health, oligodendrocytes already communicate with axons through NMDAR for trophic support ${ }^{71}$ and BK channels form complexes with this receptor ${ }^{143}$. Therefore, when activated, BK channels could protect oligodendrocytes from axon-induced excitotoxicity by increasing hyperpolarisation. Prolonging APs may increase the duration of the desensitised state of ionotropic channels and VGCCs to limit $\mathrm{Ca}^{2+}$ influx. In demyelinating pathology, the excessive excitotoxicity could inhibit the endogenous protection by BK channels to oligodendrocytes. The addition of an activator could re-open these, re-establishing protective effects. A counter argument is that high extracellular potassium is primarily responsible by increasing length of neuronal depolarised state. Damaged oligodendrocytes may have a dysfunctional inward rectifier potassium channel, so $\mathrm{K}^{+}$clearance is faulty ${ }^{144}$. Large levels of excitatory stimulation of myelin may result because when neurons are demyelinated or damaged they upregulate sodium channels, and subunits which maintain the depolarised state $^{77}$. In this scenario, BK channel activators might be counter-productive by increasing extracellular $\mathrm{K}^{+}$, but possibly only if $\mathrm{K}^{+}$clearance is faulty.

BK channel activators could be used therapeutically to preserve function in demyelinating diseases, particularly MS. As described above, currently the standard treatment for MS targets inflammation, but curbing the pathological attack by the immune system does not protect from demyelination or excitotoxicity. Therefore, it does not prevent neurodegeneration or restore functionality $\operatorname{lost}^{11}$. In MS, BK channels are expressed in both myelin and the axons it covers. Crucially, in chronically injured white matter, their activation upon $\mathrm{Ca}^{2+}$ influx was observed only upon axon exposure subsequent to chronic spinal cord injury ${ }^{128}$. Addition of the $\mathrm{BK}$ channel activator isopimaric acid preserved myelination after spinal cord injury in rats ${ }^{45}$, where functionality correlated with preserved myelinated tracts. This suggests that a BK channel activator could target demyelination to preserve functionality in MS.

Only a few BK channel activators have been studied in the clinic, BMS-204352 (Maxipost) was developed for stroke while andolast is reported to be in phase III for asthma ${ }^{129,130}$. Unoprostone isopropyl is an atypical prostanoid used topically in the treatment of glaucoma ${ }^{131}$. VSN16R was recently trialled in people with MS for muscle spasticity ${ }^{133,134,138}$. This trial focussed on spasticity endpoints up to a week after administration of the drug and no remyelination parameters were studied $^{134}$

\section{Conclusion}

There are numerous ways excessive glutamate may cause oligodendrocytes toxicity in demyelinating pathology. Neuroinflammation increases neuronal signalling which will 
damage neurons, that will release even more glutamate. The vicious cycle of damage by oxidative stress to cellular metabolism will exacerbate pathology. Close proximity to neurons, glutamatergic receptor expression and high vulnerability to oxidative stress makes oligodendrocytes particularly susceptible to excitotoxicity compared to other lesion tissue ${ }^{73,74}$. Oligodendrocytes perivascular location, as part of white matter, further increases this susceptibility, especially in MS where neuroinflammatory oxidative stress is central to demyelination.

BK channels can modulate cellular excitability and are even proposed to protect cells from release of excessive levels of excitatory neurotransmitters, by pairing with ionotropic glutamate receptors and VGCCs. It is plausible that BK channels could protect oligodendrocytes from excitotoxicity, supported by their expression in these cells ${ }^{139}$. With high levels of glutamate BK channels become inactivated, possibly explaining their inability to protect cells in models of demyelination $^{45}$. It is therefore feasible that BK channel activators might protect pathological oligodendrocytes from excitotoxic stress. Considering oligodendrocytes primary function is axon myelination, then if BK channels preserve oligodendrocytes integrity myelination would also be preserved.

There is still little evidence of the functions of BK channels on oligodendrocytes and the involvement of BK channels in MS is an angle of research that has yet to be explored extensively. Therefore, in vitro tests are fundamental to establish a first functional link between BK channels, oligodendrocytes, oxidative stress and myelin preservation to verify the importance of conducting these investigations and possibly prompt more. Crucially, it is important to determine whether BK channels are expressed by oligodendrocytes, whether this expression depends on developmental stage, but also effects of glutamate-induced excitotoxicity in the context of myelination and the ability to target $\mathrm{BK}$ channels in vivo. This would define whether increasing the open conformation of BK channels with activating agents is a promising neuroprotective therapy to be used in parallel to immunosuppressive agents for the treatment of MS.

\section{Abbreviations}

ADCC: antibody- dependent cellular cytotoxicity

AMPAR: alpha-amino-3-hydroxy-5-methyl-4-isoxazolepropionic acid receptor

AP: action potential

APC: antigen presenting cell

ATP: adenosine triphosphate

BBB: blood brain barrier

$\mathrm{BK}$ : big conductance $\mathrm{Ca}^{2+}$ activated $\mathrm{K}^{+}$(channel)

$\mathrm{CD}$ : cluster of differentiation

CNP: 2',3'-cyclic nucleotide 3'-phosphodiesterase
CNS: central nervous system

CSF: cerebrospinal fluid

$\mathrm{Cx}$ : connexin

DMEM: modified minimal essential medium

DMT: disease modifying therapy

DNA: deoxyribonucleic acid

EAE: experimental autoimmune encephalomyelitis

ERK: extracellular-signal regulated kinase

FBS: foetal bovine serum

GABA: gamma-aminobutyric acid

GAPDH: glyceraldehyde 3-phosphate dehydrogenase

GFAP: glial fibrillary acidic protein

GLUT1: glucose transporter 1

GM-CSF: granulocyte- macrophage colony stimulating factor

IFN $\gamma$ : interferon gamma

IgG: immunoglobulin G

IL: interleukin

KCNM: $\mathrm{Ca}^{2+}$-activated- $\mathrm{K}^{+}$channel subunit

Kir: inward rectifying $\mathrm{K}^{+}$channel

KO: knockout

$\mathrm{Kv1}$ : voltage gated $\mathrm{K}^{+}$channel

MAG: myelin- associated glycoprotein

MAPK: mitogen- activated protein kinase

MBP: myelin basic protein

MCT: monocarboxylate transporter

MDA: malondialdehyde

MOG: myelin oligodendrocyte glycoprotein

MRI: magnetic resonance imaging

MS: multiple sclerosis

Nav1: voltage gated $\mathrm{Na}+$ channel

NFkB: nuclear factor kappa-light-chain-enhancer of activated $B$ cells

NMDA(R): N-methyl-D-aspartate (receptor)

OPC: oligodendrocyte progenitor cell

PBS: phosphate-buffered saline

qPCR: quantitative polymerase chain reaction 
RNS: reactive nitrogen species

ROS: reactive oxygen species

RRMS: relapsing- remitting multiple sclerosis

SPMS: secondary progressive multiple sclerosis

STREX: stress-axis regulated exon

TBARs: thiobarbituric acid reactive substance assay

Th: T helper (cell)
TNF $\alpha$ : tumour necrosis factor alpha

TNF $\beta$ : tumour necrosis factor beta

TRP: transient receptor potential (channel)

VGCC: voltage gated $\mathrm{Ca}^{2+}$ channel

4-AP: 4-aminopyrimidine

Data availability

Underlying data

No data are associated with this article.
1. GBD 2016 Multiple Sclerosis Collaborators: Global, regional, and national burden of multiple sclerosis 1990-2016: a systematic analysis for the Global Burden of Disease Study 2016. Lancet Neurol. 2019; 18(3): 269-85. PubMed Abstract | Publisher Full Text | Free Full Text

2. Walton $C$, King R, Rechtman L, et al.: Rising prevalence of multiple sclerosis worldwide: Insights from the Atlas of MS, third edition. Mult Scler. 2020; 26(14): 1816-21.

PubMed Abstract | Publisher Full Text | Free Full Text

3. Cutter $\mathrm{G}$ : Is multiple sclerosis a length-dependent central axonopathy? 2016; (October): 1-24.

4. Popescu BF, Pirko I, Lucchinetti CF: Pathology of multiple sclerosis: where do we stand? Continuum (Minneap Minn). 2013; 19(4 Multiple Sclerosis): 901-21. PubMed Abstract | Publisher Full Text | Free Full Text

5. Hartley MD, Shokat MD, DeBell MJ, et al.: Pharmacological Complementation Remedies an Inborn Error of Lipid Metabolism. Cell Chem Biol. 2020; 27(5): 551-559.e4.

PubMed Abstract | Publisher Full Text | Free Full Text

6. Ascano M Jr, Mukherjee N, Bandaru P, et al.: FMRP targets distinct mRNA sequence elements to regulate protein expression. Nature. 2012; 492(7429): 382-6.

PubMed Abstract | Publisher Full Text | Free Full Text

7. Swanson MR, Wolff JJ, Shen MD, et al.: Development of white matter circuitry in infants with fragile $x$ syndrome. JAMA Psychiatry. 2018; 75(5): 505-13. PubMed Abstract | Publisher Full Text | Free Full Text

8. Doll CA, Yergert KM, Appel BH: The RNA binding protein fragile $\mathbf{X}$ mental retardation protein promotes myelin sheath growth. Glia. 2020; 68(3): 495-508.

PubMed Abstract | Publisher Full Text | Free Full Text

9. Dobson R, Giovannoni G: Multiple sclerosis - a review. Eur J Neurol. 2019; 26(1): 27-40.

PubMed Abstract | Publisher Full Text

10. Gregson A, Thompson K, Tsirka SE, et al.: Emerging small-molecule treatments for multiple sclerosis: focus on $B$ cells [version 1; peer review: 2 approved]. F1000Res. 2019; 8: F1000 Faculty Rev-245.

PubMed Abstract | Publisher Full Text | Free Full Text

11. Mahad DH, Trapp BD, Lassmann H: Pathological mechanisms in progressive multiple sclerosis. Lancet Neurol. 2015; 14(2): 183-93. PubMed Abstract | Publisher Full Text

12. Lubetzki C, Zalc B, Williams A, et al.: Remyelination in multiple sclerosis: from basic science to clinical translation. Lancet Neurol. 2020; 19(8): 678-88. PubMed Abstract | Publisher Full Text

13. Green AJ, Gelfand JM, Cree BA, et al.: Clemastine fumarate as a remyelinating therapy for multiple sclerosis (ReBUILD): a randomised, controlled, doubleblind, crossover trial. Lancet. 2017; 390(10111): 2481-9.

PubMed Abstract | Publisher Full Text

14. Neumann B, Baror R, Zhao C, et al.: Metformin Restores CNS Remyelination Capacity by Rejuvenating Aged Stem Cells. Cell Stem Cell. 2019; 25(4): 473-485.e8

PubMed Abstract | Publisher Full Text | Free Full Text

15. Brown J, Cunniffe N, Prados F, et al.: LB01.02 - Phase 2 clinical trial evidence that a retinoid-X receptor agonist promotes remyelination in people with relapsing-remitting multiple sclerosis. MS Virtual 8th Joint ACTRIMS-ECTRIMS Meeting, 2020; 11-13.

Reference Source

16. Duman $\mathrm{M}$, Vaquié $\mathrm{A}$, Nocera $\mathrm{G}$, et al.: EEF1A1 deacetylation enables transcriptional activation of remyelination. Nat Commun. 2020; 11(1): 3420. PubMed Abstract | Publisher Full Text | Free Full Text

17. Rankin KA, Mei F, Kim K, et al.: Selective estrogen receptor modulators enhance CNS remyelination independent of estrogen receptors. I Neurosci. 2019; 39(12): 2184-94.

PubMed Abstract | Publisher Full Text | Free Full Text

18. Lin Y, Huang G, Jamison S, et al:: PERK Activation Preserves the Viability and Function of Remyelinating Oligodendrocytes in Immune-Mediated Demyelinating Diseases. Am J Pathol. 2014; 184(2): 507-519.

PubMed Abstract | Publisher Full Text | Free Full Text

19. Lei Z, Yue Y, Stone S, et al.: NF-KB Activation Accounts for the Cytoprotective Effects of PERK Activation on Oligodendrocytes during EAE.J Neurosci. 2020; 40(33): 6444-6456.

PubMed Abstract | Publisher Full Text | Free Full Text

20. Stone S, Jamison S, Yue Y, et al.: NF-kB Activation Protects Oligodendrocytes against Inflammation. J Neurosci. 2017; 37(38): 9332-9344. PubMed Abstract | Publisher Full Text | Free Full Text

21. Tanner DC, Campbell A, O'Banion KM, et al.: cFLIP is critical for oligodendrocyte protection from inflammation. Cell Death Differ. 2015; 22(9): 1489-1501.

PubMed Abstract | Publisher Full Text | Free Full Text

22. Ellrichmann G, Thöne J, Lee DH, et al.: Constitutive activity of NF-kappa B in myeloid cells drives pathogenicity of monocytes and macrophages during autoimmune neuroinflammation. J Neuroinflammation. 2012; 9(1): 15. PubMed Abstract | Publisher Full Text | Free Full Text

23. Marriott MP, Emery B, Cate HS, et al.: Leukemia inhibitory factor signaling modulates both central nervous system demyelination and myelin repair. Glia. 2008; 56(6): 686-698.

PubMed Abstract | Publisher Full Text

24. Slaets H, Hendriks JJ, van den Haute C, et al.: CNS-targeted LIF Expression Improves Therapeutic Efficacy and Limits Autoimmune-mediated Demyelination in a Model of Multiple Sclerosis. Mol Ther. 2010; 18(4): 684-691.

PubMed Abstract | Publisher Full Text | Free Full Text

25. Luccarini I, Ballerini C, Biagioli T, et al:: Combined treatment with atorvastatin and minocycline suppresses severity of EAE. Exp Neurol. 2008; 211(1): 214-226.

PubMed Abstract | Publisher Full Text

26. Metz LM, Li DKB, Traboulsee AL, et al.: Trial of Minocycline in a Clinically Isolated Syndrome of Multiple Sclerosis. N EnglJ Med. 2017; 376(22): 2122-2133.

PubMed Abstract | Publisher Full Text

27. Docrat TF, Nagiah S, Naicker N, et al.: The protective effect of metformin on mitochondrial dysfunction and endoplasmic reticulum stress in diabetic mice brain. Eur J Pharmacol. 2020; 875: 173059. PubMed Abstract | Publisher Full Text

28. Xu B, Allard C, Alvarez-Mercado AI, et al.: Estrogens Promote Misfolded Proinsulin Degradation to Protect Insulin Production and Delay Diabetes. Cell Rep. 2018; 24(1): 181-196.

PubMed Abstract | Publisher Full Text | Free Full Text

29. Vergo S, Craner MJ, Etzensperger R, et al.: Acid-sensing ion channel $\mathbf{1}$ is involved in both axonal injury and demyelination in multiple sclerosis and its animal model. Brain. 2011; 134(Pt 2): 571-584. PubMed Abstract | Publisher Full Text

30. Barnett MW, Larkman PM: The action potential. Pract Neurol. 2007; 7(3): 
$192-7$.

PubMed Abstract

31. Baumann N, Pham-Dinh D: Biology of oligodendrocyte and myelin in the mammalian central nervous system. Physiol Rev. 2001; 81(2): 871-927. PubMed Abstract | Publisher Full Text

32. Waxman SG, Sims TJ: Specificity in central myelination: evidence for local regulation of myelin thickness. Brain Res. 1984; 292(1): 179-85. PubMed Abstract | Publisher Full Text

33. Hursh JB: Velocity and diameter. Am J Physiol. 1939; 127: 131-9.

34. Waxman SG, Swadlow HA: The conduction properties of axons in central white matter. Prog Neurobiol. 1977; 8(4): 297-324. PubMed Abstract | Publisher Full Text

35. Fünfschilling U, Supplie LM, Mahad D, et al.: Glycolytic oligodendrocytes maintain myelin and long-term axonal integrity. Nature. 2012; 485(7399): 517-21.

PubMed Abstract | Publisher Full Text | Free Full Text

36. Volkenhoff $A$, Weiler $A$, Letzel $M$, et al.: Glial glycolysis is essential for neuronal survival in drosophila. Cell Metab. 2015; 22(3): 437-47. PubMed Abstract | Publisher Full Text

37. Lee $Y$, Morrison BM, Li Y, et al:: Oligodendroglia metabolically support axons and contribute to neurodegeneration. Nature 2012; 487(7408): 443-8. PubMed Abstract | Publisher Full Text | Free Full Text

38. Díaz-García CM, Mongeon R, Lahmann C, et al:: Neuronal Stimulation Triggers Neuronal Glycolysis and Not Lactate Uptake. Cell Metab. 2017, 26(2): 361-374.e4.

PubMed Abstract | Publisher Full Text | Free Full Text

39. Kamasawa N, Sik A, Morita M, et al.: Connexin-47 and connexin-32 in gap junctions of oligodendrocyte somata, myelin sheaths, paranodal loops and Schmidt-Lanterman incisures: implications for ionic homeostasis and potassium siphoning. Neuroscience. 2005; 136(1): 65-86. PubMed Abstract | Publisher Full Text | Free Full Text

40. Tekkök SB, Brown AM, Westenbroek R, et al.: Transfer of glycogenderived lactate from astrocytes to axons via specific monocarboxylate transporters supports mouse optic nerve activity. J Neurosci Res. 2005; 81(5): 644-52.

PubMed Abstract | Publisher Full Text

41. Odermatt B, Wellershaus $K$, Wallraff A, et al.: Connexin 47 (Cx47)-deficient mice with enhanced green fluorescent protein reporter gene revea predominant oligodendrocytic expression of $\mathrm{Cx} 47$ and display vacuolized myelin in the CNS. J Neurosci. 2003; 23(11): 4549-59. PubMed Abstract | Publisher Full Text | Free Full Text

42. Franklin RJM, Goldman SA: Glia Disease and Repair-Remyelination. Cold Spring Harb Perspect Biol. 2015; 7(7): a020594.

PubMed Abstract | Publisher Full Text | Free Full Text

43. Metz I, Weigand SD, Popescu BFG, et al.: Pathologic heterogeneity persists in early active multiple sclerosis lesions. Ann Neurol. 2014; 75(5): 728-38. PubMed Abstract | Publisher Full Text | Free Full Text

44. Li R, Patterson KR, Bar-Or A: Reassessing B cell contributions in multiple sclerosis. Nat Immunol. 2018; 19(7): 696-707. PubMed Abstract | Publisher Full Text

45. Jacobsen M, Lett $\mathrm{K}$, Barden JM, et al.: Activation of the Large-Conductance Voltage, and $\mathrm{Ca}^{2+}$ - Activated $\mathrm{K}^{+}$(BK) Channel in Acute Spinal Cord Injury in the Wistar Rat Is Neuroprotective. Front Neurol. 2018; 9: 1107. PubMed Abstract | Publisher Full Text | Free Full Text

46. Filippi M, Bar-Or A, Piehl F, et al.: Multiple sclerosis. Nat Rev Dis Primers. 2018; 4(1): 43

PubMed Abstract | Publisher Full Text

47. Reich DS, Lucchinetti CF, Calabresi PA: Multiple sclerosis. N EnglJ Med. 2018; 378(2): 169-80.

PubMed Abstract | Publisher Full Text | Free Full Text

48. Miller DH, Barkhof F, Frank JA, et al.: Measurement of atrophy in multiple sclerosis: pathological basis, methodological aspects and clinical relevance. Brain. 2002; 125(Pt 8): 1676-95. PubMed Abstract | Publisher Full Text

49. Salzer J, Svenningsson A, Sundström P: Neurofilament light as a prognostic marker in multiple sclerosis. Mult Scler. 2010; 16(3): 287-92. PubMed Abstract | Publisher Full Text

50. Franklin RJM, Frisén J, Lyons DA: Revisiting remyelination: Towards a consensus on the regeneration of CNS myelin. Semin Cell Dev Biol. 2021; 116: 3-9. PubMed Abstract | Publisher Full Text

51. Dawson MRL, Polito A, Levine JM, et al.: NG2-expressing glial progenitor cells: An abundant and widespread population of cycling cells in the adult rat CNS. Mol Cell Neurosci. 2003; 24(2): 476-88. PubMed Abstract | Publisher Full Text

52. Miron VE, Boyd A, Zhao JW, et al.: M2 microglia and macrophages drive oligodendrocyte differentiation during CNS remyelination. Nat Neurosci. 2013; 16(9): 1211-8.

PubMed Abstract | Publisher Full Text | Free Full Text

53. Redford EJ, Kapoor R, Smith KJ: Nitric oxide donors reversibly block axona conduction: Demyelinated axons are especially susceptible. Brain. 1997; 120(Pt 12): 2149-57.

PubMed Abstract | Publisher Full Text
54. Blakemore WF: Pattern of remyelination in the CNS. Nature. 1974; 249(457): $577-8$

PubMed Abstract | Publisher Full Text

55. Goldschmidt T, Antel J, König FB, et al.: Remyelination capacity of the MS brain decreases with disease chronicity. Neurology. 2009; 72(22): 1914-21. PubMed Abstract | Publisher Full Text

56. Aggarwal S, Snaidero N, Pähler G, et al.: Myelin Membrane Assembly Is Driven by a Phase Transition of Myelin Basic Proteins Into a Cohesive Protein Meshwork. PLOS Biol. 2013; 11(6): e1001577. PubMed Abstract | Publisher Full Text | Free Full Text

57. Snaidero N, Möbius W, Czopka T, et al:: Myelin membrane wrapping of CNS axons by $\mathrm{PI}(3,4,5) \mathrm{P3}$-dependent polarized growth at the inner tongue. Cell. 2014; 156(1-2): 277-90.

PubMed Abstract | Publisher Full Text | Free Full Text

58. Griffiths I, Klugmann M, Anderson T, et al.: Axonal swellings and degeneration in mice lacking the major proteolipid of myelin. Science. 1998 280(5369): 1610-3.

PubMed Abstract | Publisher Full Text

59. Snaidero N, Velte C, Myllykoski M, et al:: Antagonistic Functions of MBP and CNP Establish Cytosolic Channels in CNS Myelin. Cell Rep. 2017; 18(2): 314-23.

PubMed Abstract | Publisher Full Text | Free Full Text

60. Lappe-Siefke C, Goebbels S, Gravel M, et al.: Disruption of Cnp1 uncouples oligodendroglial functions in axonal support and myelination. Nat Genet. 2003; 33(3): 366-74

PubMed Abstract | Publisher Full Text

61. Salami M, Itami C, Tsumoto T, et al:: Change of conduction velocity by regional myelination yields constant latency irrespective of distance between thalamus and cortex. Proc Natl Acad Sci U S A. 2003; 100(10): 6174-9. PubMed Abstract | Publisher Full Text | Free Full Text

62. Barres BA, Raff MC: Proliferation of oligodendrocyte precursor cells depends on electrical activity in axons. Nature. 1993; 361(6409): 258-60. PubMed Abstract | Publisher Full Text

63. Demerens C, Stankoff B, Logak M, et al.: Induction of myelination in the central nervous system by electrical activity. Proc Natl Acad Sci U S A. 1996; 93(18): 9887-92.

PubMed Abstract | Publisher Full Text | Free Full Text

64. Möbius W, Nave KA, Werner HB: Electron microscopy of myelin: Structure preservation by high-pressure freezing. Brain Res. 2016; 1641(Pt A): 92-100. PubMed Abstract | Publisher Full Text

65. Hansen KB, Yi F, Perszyk RE, et al.: Structure, function, and allosteric modulation of NMDA receptors. J Gen Physiol. 2018; 150(8): 1081-1105. PubMed Abstract | Publisher Full Text | Free Full Text

66. Wake $\mathrm{H}$, Lee PR, Douglas Fields R: Control of local protein synthesis and initial events in myelination by action potentials. Science. 2011; 333(6049): $1647-51$

PubMed Abstract | Publisher Full Text | Free Full Text

67. Bergles DE, Roberts JD, Somogyl P, et al.: Glutamatergic synapses on oligodendrocyte precursor cells in the hippocampus. Nature. 2000 405(6783): 187-91.

PubMed Abstract | Publisher Full Tex

68. Gibson EM, Purger D, Mount CW, et al.: Neuronal activity promotes oligodendrogenesis and adaptive myelination in the mammalian brain. Science. 2014: 344(6183): 1252304

PubMed Abstract | Publisher Full Text | Free Full Text

69. Etxeberria A, Hokanson KC, Dao DQ, et al.: Dynamic modulation of myelination in response to visual stimuli alters optic nerve conduction velocity. J Neurosci. 2016; 36(26): 6937-48.

PubMed Abstract | Publisher Full Text | Free Full Text

70. Micu I, Plemel JR, Lachance $C$, et al:: The molecular physiology of the axomyelinic synapse. Exp Neurol. 2016; 276: 41-50.

PubMed Abstract | Publisher Full Text

71. Saab AS, Tzvetavona ID, Trevisiol A, et al.: Oligodendroglial NMDA Receptors Regulate Glucose Import and Axonal Energy Metabolism. Neuron. 2016; 91(1): 119-32

PubMed Abstract | Publisher Full Text

72. Frühbeis C, Fröhlich D, Kuo WP, et al.: Neurotransmitter-Triggered Transfer of Exosomes Mediates Oligodendrocyte-Neuron Communication. PLOS Biol. 2013; 11(7): e1001604.

PubMed Abstract | Publisher Full Text | Free Full Text

73. Tolosa L, Caraballo-Miralles V, Olmos G, et al.: TNF- $\alpha$ potentiates glutamateinduced spinal cord motoneuron death via NF-KB. Mol Cell Neurosci. 2011 46(1): 176-86.

PubMed Abstract | Publisher Full Text

74. Domercq M, Alberdi E, Sánchez-Gómez MV, et al:: Dual-specific phosphatase-6 (Dusp6) and ERK mediate AMPA receptor-induced oligodendrocyte death. J Biol Chem. 2011; 286(13): 11825-36.

PubMed Abstract | Publisher Full Text | Free Full Text

75. Lu F, Selak M, O'Connor J, et al.: Oxidative damage to mitochondrial DNA and activity of mitochondrial enzymes in chronic active lesions of multiple sclerosis. J Neurol Sci. 2000; 177(2): 95-103.

PubMed Abstract | Publisher Full Text

76. Dixon SJ, Lemberg KM, Lamprecht MR, et al.: Ferroptosis: An iron-dependent 
form of nonapoptotic cell death. Cell. 2012; 149(5): 1060-72.

PubMed Abstract | Publisher Full Text | Free Full Text

77. Young EA, Fowler CD, Kidd GJ, et al.: Imaging correlates of decreased axonal $\mathrm{Na}^{+} / \mathrm{K}^{+}$ATPase in chronic multiple sclerosis lesions. Ann Neurol. 2008; 63(4): 428-35.

PubMed Abstract | Publisher Full Text

78. Nikić I, Merkler D, Sorbara C, et al:: A reversible form of axon damage in experimental autoimmune encephalomyelitis and multiple sclerosis. Nat Med. 2011; 17(4): 495-9.

PubMed Abstract | Publisher Full Text

79. Sarchielli $P$, Greco L, Floridi A, et al.: Excitatory amino acids and multiple sclerosis: Evidence from cerebrospinal fluid. Arch Neurol. 2003; 60(8): 1082-8. PubMed Abstract | Publisher Full Text

80. Baranzini $S E$, Srinivasan $R$, Khankhanian $P$, et al.: Genetic variation influences glutamate concentrations in brains of patients with multiple sclerosis. Brain. 2010; 133(9): 2603-11.

PubMed Abstract | Publisher Full Text | Free Full Text

81. Ye $L$, Huang $Y, Z$ hao $L$, et al.: IL-1 $\beta$ and TNF- $\alpha$ induce neurotoxicity through glutamate production: A potential role for neuronal glutaminase. J Neurochem. 2013; 125(6): 897-908.

PubMed Abstract | Publisher Full Text | Free Full Text

82. Takahashi JL, Giuliani F, Power C, et al.: Interleukin-1 $\beta$ promotes oligodendrocyte death through glutamate excitotoxicity. Ann Neurol. 2003; 53(5): 588-95.

PubMed Abstract | Publisher Full Text

83. Rossi S, Furlan R, De Chiara V, et al.: Interleukin-1 $\beta$ causes synaptic hyperexcitability in multiple sclerosis. Ann Neurol. 2012; 71(1): 76-83. PubMed Abstract | Publisher Full Text

84. Pampliega O, Domercq M, Soria FN, et al.: Increased expression of cystine/ glutamate antiporter in multiple sclerosis. J Neuroinflammation. 2011; 8: 63. PubMed Abstract | Publisher Full Text | Free Full Text

85. Piña-Crespo JC, Talantova M, Micu I, et al.: Excitatory glycine responses of CNS myelin mediated by NR1/NR3 “NMDA" receptor subunits. J Neurosci. 2010; 30(34): 11501-5.

PubMed Abstract | Publisher Full Text | Free Full Text

86. Kapoor R, Furby J, Hayton T, et al.: Lamotrigine for neuroprotection in secondary progressive multiple sclerosis: a randomised, double-blind, placebo-controlled, parallel-group trial. Lancet Neurol. 2010; 9(7): 681-8. PubMed Abstract | Publisher Full Text

87. Gnanapavan S, Grant D, Morant S, et al.: Biomarker Report from the Phase II Lamotrigine Trial in Secondary Progressive MS - Neurofilament as a Surrogate of Disease Progression. PLoS One. 2013; 8(8): e70019. PubMed Abstract | Publisher Full Text | Free Full Text

88. van Horssen J, Schreibelt G, Drexhage J, et al.: Severe oxidative damage in multiple sclerosis lesions coincides with enhanced antioxidant enzyme expression. Free Radic Biol Med. 2008; 45(12): 1729-37. PubMed Abstract | Publisher Full Text

89. Juurlink $\mathrm{BH}$ : Response of glial cells to ischemia: Roles of reactive oxygen species and glutathione. Neurosci Biobehav Rev. 1997; 21(2): 151-66. PubMed Abstract | Publisher Full Text

90. Villoslada P, Arrondo G, Sepulcre J, et al.: Memantine induces reversible neurologic impairment in patients with MS. Neurology. 2009; 72(19): 1630-3. PubMed Abstract | Publisher Full Text

91. Waubant $\mathrm{E}$, Maghzi $\mathrm{AH}$, Revirajan $\mathrm{N}$, et al.: A randomized controlled phase II trial of riluzole in early multiple sclerosis. Ann Clin Transl Neurol. 2014; 1(5): 340-7.

PubMed Abstract | Publisher Full Text | Free Full Text

92. Mehta LR, McDermott MP, Goodman AD, et al:: A randomized trial of memantine as treatment for spasticity in multiple sclerosis. Mult Scler. 2010; 16(2): 248-51.

PubMed Abstract | Publisher Full Text

93. Krupp LB, Coyle PK, Doscher C, et al.: Fatigue therapy in multiple sclerosis: results of a double-blind, randomized, parallel trial of amantadine, pemoline, and placebo. Neurology. 1995; 45(11): 1956 LP-1961. PubMed Abstract | Publisher Full Text

94. Chataway J, De Angelis F, Connick $P$, et al.: Efficacy of three neuroprotective drugs in secondary progressive multiple sclerosis (MS-SMART): a phase $\mathbf{2 b}$ multiarm, double-blind, randomised placebo-controlled trial. Lancet Neurol. 2020; 19(3): 214-25.

PubMed Abstract | Publisher Full Text | Free Full Text

95. Raftopoulos R, Hickman SJ, Toosy A, et al.: Phenytoin for neuroprotection in patients with acute optic neuritis: a randomised, placebo-controlled, phase 2 trial. Lancet Neurol. 2016; 15(3): 259-69. PubMed Abstract | Publisher Full Text

96. Marta M, Bianchi L, Lieberman D, et al:: Oxcarbazepine as a neuroprotective agent in MS: a phase IIa trial (PROXIMUS). ECTRIMS Online Library, 2019. Reference Source

97. McCracken E, Valeriani V, Simpson C, et al.: The lipid peroxidation by-product 4-hydroxynonenal is toxic to axons and oligodendrocytes. J Cereb Blood Flow Metab. 2000; 20(11): 1529-36.

PubMed Abstract | Publisher Full Text

98. Hametner $S$, Wimmer I, Haider $L$, et al.: Iron and neurodegeneration in the multiple sclerosis brain. Ann Neurol. 2013; 74(6): 848-61. PubMed Abstract | Publisher Full Text | Free Full Tex

99. Domercq M, Etxebarria E, Pérez-Samartín A, et al.: Excitotoxic oligodendrocyte death and axonal damage induced by glutamate transporter inhibition Glia. 2005; 52(1): 36-46. PubMed Abstract | Publisher Full Text

100. Pitt $D$, Werner $P$, Raine $C S$ : Glutamate excitotoxicity in a model of multiple sclerosis. Nat Med. 2000; 6(1): 67-70. PubMed Abstract | Publisher Full Text

101. Alberdi E, Sánchez-Gómez MV, Marino A, et al: $\mathrm{Ca}(2+)$ influx through AMPA or kainate receptors alone is sufficient to initiate excitotoxicity in cultured oligodendrocytes. Neurobiol Dis. 2002; 9(2): 234-43. PubMed Abstract | Publisher Full Text

102. Micu I, Jiang Q, Coderre $E$, et al.: NMDA receptors mediate calcium accumulation in myelin during chemical ischaemia. Nature. 2006; 439(7079): 988-92. PubMed Abstract | Publisher Full Text

103. Hamilton NB, Kolodziejczyk K, Kougioumtzidou E, et al.: Proton-gated $\mathrm{Ca}(2+)$-permeable TRP channels damage myelin in conditions mimicking ischaemia. Nature. 2016; 529(7587): 523-7. PubMed Abstract | Publisher Full Text | Free Full Text

104. Butler A, Tsunoda S, McCobb DP, et al.: $\boldsymbol{m S l o}$, a complex mouse gene encoding "maxi" calcium-activated potassium channels. Science. 1993; 261(5118): 221-4. PubMed Abstract | Publisher Full Text

105. Magleby KL: Gating mechanism of BK (Slo1) channels: So near, yet so far. J Gen Physiol. 2003; 121(2): 81-96. PubMed Abstract | Publisher Full Text | Free Full Text

106. Salkoff L, Butler A, Ferreira G, et al.: High-conductance potassium channels of the SLO family. Nat Rev Neurosci. 2006; 7(12): 921-31. PubMed Abstract | Publisher Full Text

107. Fakler B, Adelman JP: Control of $\mathbf{K}(\mathrm{Ca})$ channels by calcium nano/ microdomains. Neuron. 2008; 59(6): 873-81. PubMed Abstract | Publisher Full Text

108. Kurt S, Sausbier M, Rüttiger L, et al.: Critical role for cochlear hair cell BK channels for coding the temporal structure and dynamic range of auditory information for central auditory processing. FASEB J. 2012; 26(9): 3834-43. PubMed Abstract | Publisher Full Text | Free Full Text

109. Erxleben C, Everhart AL, Romeo C, et al.: Interacting effects of $\mathbf{N}$-terminal variation and strex exon splicing on slo potassium channel regulation by calcium, phosphorylation, and oxidation. J Biol Chem. 2002; 277(30): 27045-52.

PubMed Abstract | Publisher Full Text

110. Wallner $M$, Meera $P$, Toro $L$ : Determinant for beta-subunit regulation in high-conductance voltage-activated and $\mathrm{Ca}(2+)$-sensitive $\mathrm{K}^{+}$channels: an additional transmembrane region at the $\mathbf{N}$ terminus. Proc Natl Acad Sci U S A. 1996; 93(25): 14922-7.

PubMed Abstract | Publisher Full Text | Free Full Text

111. Dworetzky SI, Boissard CG, Lum-Ragan JT, et al.: Phenotypic alteration of a human BK (hSlo) channel by hSlobeta subunit coexpression: changes in blocker sensitivity, activation/relaxation and inactivation kinetics, and protein kinase A modulation. J Neurosci. 1996; 16(15): 4543-50. PubMed Abstract | Publisher Full Text | Free Full Text

112. Zhang $Y Y, \operatorname{Han} X$, Liu $Y$, et al.: +mRNA expression of LRRC55 protein (leucinerich repeat-containing protein $\mathbf{5 5}$ ) in the adult mouse brain. PLOS One. 2018 13(1): e0191749.

PubMed Abstract | Publisher Full Text | Free Full Text

113. Engbers JDT, Anderson D, Zamponi GW, et al.: Signal processing by T-type calcium channel interactions in the cerebellum. Front Cell Neurosci. 2013; 7: 230.

PubMed Abstract | Publisher Full Text | Free Full Text

114. Berkefeld $\mathrm{H}$, Fakler $\mathrm{B}$ : Repolarizing responses of $\mathbf{B K}_{\mathrm{ca}}$-cav complexes are distinctly shaped by their cav subunits. J Neurosci. 2008; 28(33): 8238-45. PubMed Abstract | Publisher Full Text | Free Full Text

115. Signaling CK, Berkefeld $\mathrm{H}$, Sailer CA, et al: BK Ca -Cav Channel Complexes. Science (80-). 2006; (October): 615-21.

116. Wang $B$, Bugay $V$, Ling $L$, et al.: Knockout of the BK $\beta_{4}$-subunit promotes a functional coupling of $B K$ channels and ryanodine receptors that mediate a fAHP-induced increase in excitability. I Neurophysiol. 2016; 116(2): 456-65. PubMed Abstract | Publisher Full Text | Free Full Text

117. Moroni A, Gorza L, Beltrame M, et al.: Hyperpolarization-activated Cyclic Nucleotide-gated Channel 1 Is a Molecular Determinant of the Cardiac Pacemaker Current I(f). J Biol Chem. 2001; 276(31): 29233-41. PubMed Abstract | Publisher Full Text

118. Gu N, Vervaeke K, Storm JF: BK potassium channels facilitate high-frequency firing and cause early spike frequency adaptation in rat CA1 hippocampal pyramidal cells. J Physiol. 2007; 580(Pt.3): 859-82. PubMed Abstract | Publisher Full Text | Free Full Text

119. Matthews EA, Weible AP, Shah S, et al.: The BK-mediated fAHP is modulated by learning a hippocampus-dependent task. Proc Natl Acad Sci U S A. 2008; 105(39): 15154-9.

PubMed Abstract | Publisher Full Text | Free Full Text

120. Nelson AB, Gittis AH, du Lac S: Decreases in CaMKII activity trigger persistent potentiation of intrinsic excitability in spontaneously firing vestibular nucleus neurons. Neuron. 2005; 46(4): 623-31.

PubMed Abstract | Publisher Full Text

121. Indriati DW, Kamasawa N, Matsui K, et al.: Quantitative localization of Cav2.1 (P/Q-Type) voltage-dependent calcium channels in Purkinje 
cells: Somatodendritic gradient and distinct somatic Coclustering with calcium-activated potassium channels. J Neurosci. 2013; 33(8): 3668-78. PubMed Abstract | Publisher Full Text | Free Full Text

122. Raffaelli G, Saviane C, Mohajerani MH, et al.: BK potassium channels control transmitter release at CA3-CA3 synapses in the rat hippocampus.J Physiol. 2004; 557(1): 147-57.

PubMed Abstract | Publisher Full Text | Free Full Text

123. Fon EA, Edwards RH: Molecular mechanisms of neurotransmitter release. Muscle Nerve. 2001; 24(5): 581-601. PubMed Abstract | Publisher Full Text

124. Samengo I, Currò D, Barrese V, et al.: Large conductance calcium-activated potassium channels: Their expression and modulation of glutamate release from nerve terminals isolated from rat trigeminal caudal nucleus and cerebral cortex. Neurochem Res. 2014; 39(5): 901-10. PubMed Abstract | Publisher Full Text

125. Liao Y, Kristiansen AM, Oksvold CP, et al.: Neuronal $\mathrm{Ca}^{2+}$-activated $\mathbf{K}^{+}$channels limit brain infarction and promote survival. PLOS One. 2010; 5(12): e15601. PubMed Abstract | Publisher Full Text | Free Full Text

126. $\mathrm{Hu} \mathrm{H}$, Shao LR, Chavoshy $\mathrm{S}$, et al.: Presynaptic $\mathrm{Ca}^{2+}$-activated $\mathbf{K}^{+}$channels in glutamatergic hippocampal terminals and their role in spike repolarization and regulation of transmitter release. J Neurosci. 2001; 21(24): 9585-97.

PubMed Abstract | Publisher Full Text | Free Full Text

127. Mancini M, Soldovieri MV, Gessner G, et al: Critical role of large-conductance calcium- and voltage-activated potassium channels in leptin-induced neuroprotection of $\mathrm{N}$-methyl-d-aspartate-exposed cortical neurons. Pharmacol Res. 2014; 87: 80-6.

PubMed Abstract | Publisher Full Text | Free Full Text

128. Ye $\mathrm{H}$, Buttigieg J, Wan $\mathrm{Y}$, et al.: Expression and functional role of BK channels in chronically injured spinal cord white matter. Neurobiol Dis. 2012; $\mathbf{4 7 ( 2 )}$ 225-36.

PubMed Abstract | Publisher Full Text

129. Jensen BS: BMS-204352: A potassium channel opener developed for the treatment of stroke. CNS Drug Rev. 2002; 8(4): 353-60. PubMed Abstract | Publisher Full Text | Free Full Text

130. Malerba M, Amato MD, Radaeli A, et al.: Efficacy of Andolast in Mild to Moderate Asthma: A Randomized, Controlled, Double-Blind Multicenter Study (The Andast Trial). Curr Pharm Des, 2015; 21(26): 3835-43. PubMed Abstract | Publisher Full Text

131. Cuppoletti J, Malinowska DH, Tewari KP, et al.: Unoprostone isopropyl and metabolite M1 activate BK channels and prevent ET-1-induced $\left[\mathrm{Ca}^{2+}\right]$ increases in human trabecular meshwork and smooth muscle. Invest Ophthalmol Vis Sci. 2012; 53(9): 5178-89. PubMed Abstract | Publisher Full Text

132. Balderas E, Zhang J, Stefani E, et al:: Mitochondrial BKCa channel. Front Physiol. 2015; 6: 104

PubMed Abstract | Publisher Full Text | Free Full Text
133. Tabatabaee S, Baker D, Selwood DL, et al.: The cannabinoid-like compound, vsn $16 r$, acts on large conductance, $\mathrm{ca}^{2+}$-activated $\mathbf{k}^{+}$channels to modulate hippocampal ca1 pyramidal neuron firing. Pharmaceuticals (Basel). 2019; 12(3): 104. PubMed Abstract | Publisher Full Text | Free Full Text

134. Farrell RA, Selwood DL, Baker D: Results from a phase II proof of concept trial of VSN16R to treat multiple sclerosis related spasticity. 2018. Reference Source

135. Jäkel S, Agirre E, Mendanha Falcão A, et al:: Altered human oligodendrocyte heterogeneity in multiple sclerosis. Nature. 2019; 566(7745): 543-7. PubMed Abstract | Publisher Full Text | Free Full Text

136. Falcão $A M$, van Bruggen $D$, Marques $S$, et al.: Disease-specific oligodendrocyte lineage cells arise in multiple sclerosis. Nat Med. 2018; 24(12): 1837-44. PubMed Abstract | Publisher Full Text | Free Full Text

137. Zhang Y, Chen K, Sloan SA, et al.: An RNA-sequencing transcriptome and splicing database of glia, neurons, and vascular cells of the cerebral cortex. J Neurosci. 2014; 34(36): 11929-47. PubMed Abstract | Publisher Full Text | Free Full Text

138. Baker D, Pryce G, Visintin C, et al.: Big conductance calcium-activated potassium channel openers control spasticity without sedation. $\mathrm{Br}$ Pharmacol. 2017: 174(16): 2662-81. PubMed Abstract | Publisher Full Text | Free Full Text

139. Buttigieg J, Eftekharpour E, Karimi-Abdolrezaee $S$, et al.: Molecular and electrophysiological evidence for the expression of BK channels in oligodendroglial precursor cells. Eur J Neurosci. 2011; 34(4): 538-47. PubMed Abstract | Publisher Full Text

140. Krasnow AM, Attwell D: NMDA Receptors: Power Switches for Oligodendrocytes. Neuron. 2016; 91(1): 3-5. PubMed Abstract | Publisher Full Text

141. Larson VA, Zhang Y, Bergles DE: Electrophysiological properties of NG2(+) cells: Matching physiological studies with gene expression profiles. Brain Res. 2016; 1638(Pt B): 138-60. PubMed Abstract | Publisher Full Text | Free Full Text

142. Káradóttir $\mathrm{R}$, Cavelier $\mathrm{P}$, Bergersen $\mathrm{LH}$, et al.: NMDA receptors are expressed in oligodendrocytes and activated in ischaemia. Nature. 2005; 438(7071): $1162-6$. PubMed Abstract | Publisher Full Text | Free Full Text

143. Zhang J, Guan X, Li Q, et al:: Glutamate-activated BK channel complexes formed with NMDA receptors. Proc Natl Acad Sci U S A. 2018; 115(38): E9006-14. PubMed Abstract | Publisher Full Text | Free Full Text

144. Neusch C, Rozengurt N, Jacobs RE, et al.: Kir4.1 potassium channel subunit is crucial for oligodendrocyte development and in vivo myelination. J Neurosci. 2001; 21(15): 5429-38.

PubMed Abstract | Publisher Full Text | Free Full Text 


\section{Open Peer Review}

\section{Current Peer Review Status:}

\section{Version 2}

Reviewer Report 16 November 2021

https://doi.org/10.5256/f1000research.78993.r100202

(C) 2021 Lin W. This is an open access peer review report distributed under the terms of the Creative Commons Attribution License, which permits unrestricted use, distribution, and reproduction in any medium, provided the original work is properly cited.
Wensheng Lin
Department of Neuroscience, University of Minnesota, Minneapolis, MN, USA
No further comments.
Competing Interests: No competing interests were disclosed.
Reviewer Expertise: oligodendrocyte biology and pathology
I confirm that I have read this submission and believe that I have an appropriate level of expertise to confirm that it is of an acceptable scientific standard.

\section{Version 1}

Reviewer Report 27 September 2021

\section{https://doi.org/10.5256/f1000research.56803.r94510}

(C) 2021 Lin W. This is an open access peer review report distributed under the terms of the Creative Commons Attribution License, which permits unrestricted use, distribution, and reproduction in any medium, provided the original work is properly cited.

\section{?ensheng Lin}

Department of Neuroscience, University of Minnesota, Minneapolis, MN, USA

This review summarizes the current literature on the role of excitotoxic stress, myelination, and BK channels in MS pathology. The topic is timely and important. The manuscript is well written. However, there are a couple of concerns:

1. The authors stated that "preserving myelin might provide a better neuroprotective strategy 
than remyelination". In fact, this manuscript concentrates on demyelination, rather than remyelination. It could be better to replace remyelination with demyelination in the title.

2. This manuscript concentrates on demyelination, particularly in MS. It is important to summarize the current literature on mechanisms governing mature oligodendrocyte viability in MS and its animal models. Recent studies demonstrate the critical roles of PERK, NF-kB, among other signaling pathways in modulating oligodendrocyte viability and demyelination in MS and its animal models. These studies should be cited and discussed.

Is the topic of the review discussed comprehensively in the context of the current literature?

Yes

Are all factual statements correct and adequately supported by citations?

Yes

Is the review written in accessible language?

Yes

Are the conclusions drawn appropriate in the context of the current research literature? Yes

Competing Interests: No competing interests were disclosed.

Reviewer Expertise: oligodendrocyte biology and pathology

I confirm that I have read this submission and believe that I have an appropriate level of expertise to confirm that it is of an acceptable scientific standard, however I have significant reservations, as outlined above.

Author Response 01 Nov 2021

David Selwood, University College London, London, UK

We would like to thank Prof Lin for his careful reading of the manuscript and useful comments.

Pt 1. The reviewer asks if replacing "remyelination" with "demyelination" in the title would be more reflective of the review. The reviewer is correct in ascribing much of the review subject to demyelination, however, using "demyelination" in the title would make an association of demyelination with BK channels that would not be correct and we would not wish to do this. We think the modified title "Oligodendrocytes, BK channels and the preservation of myelin" could be a better reflection of the subject and aims of the review.

Pt 2. It is important to consider other targets that may protect mature oligodendrocytes from demyelinating pathologies like multiple sclerosis. This is to establish whether BK 
channel activators could be a valid alternative or complement existing approaches.

Another strategy could modulate the unfolded protein response (UPR) to preserve cell viability during periods of endoplasmic reticulum stress, like those caused by excessive inflammation, by temporarily halting translation to attempt re-establishing protein homeostasis. We will insert the text below into the final version of the manuscript.

Pancreatic endoplasmic reticulum kinase (PERK) is implicated in this. Increasing PERK activation in mouse models of MS protected myelin, in the presence of MS- related cytokine interferon- $y$ (133). This even improved survival of remyelinating oligodendrocytes and recovery in demyelinated lesions (133). A later study indicated that the PERK protective pathway can be enhanced by nuclear factor $K B$ (NFKB) activation (134). Oligodendrocytes were rescued only in mice with MOG- induced EAE and PERK gene deficiency, whilst healthy oligodendrocytes remained unaffected (134). This might indicate this UPR signalling pathway specifically protects from inflammatory and demyelinating pathology. Studies have replicated these cytoprotective effects, but also indicated the need for targeted activation of NFkB $(135,136,134)$. Excessive generalised activation may worsen inflammation by dysregulating immunity and promoting autoimmune reactions, possibly leading to adverse effects (137).

Alternatively, the leukaemia inhibitory factor (LIF), of the IL-6 cytokine family, was also proposed to protect mature oligodendrocytes from demyelination. Its levels determine growth and differentiation of inflammatory cells, but also possibly neural cells. Exogenous LIF protected against demyelination in cuprizone induced mouse models of MS with knockout endogenous LIF (138). Since cuprizone is toxic to oligodendrocytes but does not elicit an inflammatory response as seen in the EAE model, the authors indicated this method is directly cytoprotective (138). However, some studies suggest its activation might lead to negative effects on neuroinflammation, and state limited ability to cross the BBB when administered therapeutically; although its delivery and effectiveness significantly improved when using lentiviral vectors for CNS- specific expression in murine models $(139,138)$.

Similarly, agents aimed at attenuating the inflammation were also discovered to have independent neuroprotective effects which can lead to reduced demyelination. For example repurposing the antibiotic minocycline, which is thought to enhance anti-apoptotic signalling and was combined with atorvastatin to achieve an enhanced reduction in EAE severity (140). In a randomised controlled trial, taking minocycline within the first 6 months of the clinically isolated syndrome significantly decreased the risk of developing MS but not after two years, which may suggest a delaying instead of disease- modifying effect (141).

Finally, in the MS lesion microenvironment, the excessive inflammation and failure of energy metabolism may lead to acidosis and subsequent activation of acid sensing ion channels (ASICs), which were found upregulated in both axons and oligodendrocytes in active MS lesions (142). These proton gated cation channels are activated in similar conditions of excitotoxicity as the BK channel. Amiloride or psalmotoxin-1, blocking respectively ASICS or ASIC1, protected oligodendrocytes from injury related to this acidosis, and the EAE mouse model with knockout ASIC1 had increased levels of myelin immunostaining compared to wild type (142).

\section{References:}

133. Lin, Y., Huang, G., Jamison, S. \& Li, J. et al. (2014) PERK Activation Preserves the Viability 
and Function of Remyelinating Oligodendrocytes in Immune-Mediated Demyelinating Diseases. The American Journal of Pathology. [Online] 184 (2), 507-519. Available from: doi:10.1016/j.ajpath.2013.10.009.

134. Lei, Z., Yue, Y., Stone, S. \& Wu, S. et al. (2020) NF-kB Activation Accounts for the Cytoprotective Effects of PERK Activation on Oligodendrocytes during EAE. The Journal of Neuroscience. [Online] 40 (33), 6444-6456. Available from: doi:10.1523/jneurosci.115620.2020.

135. Stone, S., Jamison, S., Yue, Y. \& Durose, W. et al. (2017) NF-kB Activation Protects Oligodendrocytes against Inflammation. The Journal of Neuroscience. [Online] 37 (38), $9332-$ 9344. Available from: doi:10.1523/jneurosci.1608-17.2017.

136. Tanner, D., Campbell, A., O'Banion, K. \& Noble, M. et al. (2015) cFLIP is critical for oligodendrocyte protection from inflammation. Cell Death \& Differentiation. [Online] 22 (9), 1489-1501. Available from: doi:10.1038/cdd.2014.237.

137. Ellrichmann, G., Thöne, J., Lee, D. \& Rupec, R. et al. (2012) Constitutive activity of NFkappa $B$ in myeloid cells drives pathogenicity of monocytes and macrophages during autoimmune neuroinflammation. Journal of Neuroinflammation. [Online] 9 (1). Available from: doi:10.1186/1742-2094-9-15.

138. Marriott, M., Emery, B., Cate, H. \& Binder, M. et al. (2008) Leukemia inhibitory factor signaling modulates both central nervous system demyelination and myelin repair. Glia. [Online] 56 (6), 686-698. Available from: doi:10.1002/glia.20646.

139. Slaets, H., Hendriks, J., Van den Haute, C. \& Coun, F. et al. (2010) CNS-targeted LIF Expression Improves Therapeutic Efficacy and Limits Autoimmune-mediated Demyelination in a Model of Multiple Sclerosis. Molecular Therapy. [Online] 18 (4), 684-691. Available from: doi:10.1038/mt.2009.311.

140. Luccarini, I., Ballerini, C., Biagioli, T. \& Biamonte, F. et al. (2008) Combined treatment with atorvastatin and minocycline suppresses severity of EAE. Experimental Neurology. [Online] 211 (1), 214-226. Available from: doi:10.1016/j.expneurol.2008.01.022.

141. Metz, L., Li, D., Traboulsee, A. \& Duquette, P. et al. (2017) Trial of Minocycline in a Clinically Isolated Syndrome of Multiple Sclerosis. New England Journal of Medicine. [Online] 376 (22), 2122-2133. Available from: doi:10.1056/nejmoa1608889.

142. Vergo, S., Craner, M., Etzensperger, R. \& Attfield, K. et al. (2011) Acid-sensing ion channel 1 is involved in both axonal injury and demyelination in multiple sclerosis and its animal model. Brain. [Online] 134 (2), 571-584. Available from: doi:10.1093/brain/awq337.

Competing Interests: No further competing interests

Reviewer Report 26 August 2021

https://doi.org/10.5256/f1000research.56803.r91531

(C) 2021 Balderas-Angeles E et al. This is an open access peer review report distributed under the terms of the Creative Commons Attribution License, which permits unrestricted use, distribution, and reproduction in any medium, provided the original work is properly cited. 


\section{Enrique Balderas-Angeles}

Nora Eccles Harrison Cardiovascular Research \& Training Institute, University of Utah, Salt Lake City, UT, USA

\section{Veronica Loyo-Celis}

Departamento de Genética del Desarrollo y Fisiología Molecular, Instituto de Biotecnología Universidad Nacional Autónoma de México, Cuernavaca, Morelos, Mexico

\section{Is the topic of the review discussed comprehensively in the context of the current literature?}

In the review by Rupnik et al., the role of excitotoxicity in oligodendrocytes was approached through a physiological, clinical, and biophysical perspective, which allows the reader to understand the basics on the origin, progression, and possible therapies for diseases associated with demyelination.

\section{Are all factual statements correct and adequately supported by citations?}

In the manuscript by Rupnik et al., the statements were adequately supported by citations which included some classic works (Hursh, 1939'1; Waxman et al., 1977²; Waxman et al., 1984³) and articles published in the last ten years.

\section{Is the review written in accessible language?}

The review was written fluently, clearly and the topics were discussed deeply enough. The structure of the paper was clearly defined at the beginning of the text (page 3).

\section{Are the conclusions drawn appropriate in the context of the current research literature?}

The authors summarized the causes and effects of oligodendrocytes toxicity and proposed an alternative therapy to treat pathologies associated with demyelination. One strategy involves modulation of the large conductance, $\mathrm{Ca}^{2+}$ and voltage-activated BKCa channel, which activation might prevent $\mathrm{Ca}^{2+}$ overload to protect oligodendrocytes from excitotoxic stress. Of note, a similar mechanism has been observed in cardiac mitochondria in rodents, where the BKCa channel expresses and its activation reduces the driving force for $\mathrm{Ca}^{2+}$, preventing overload and cell death (Singh et al., 20134; Balderas et al., 20195). Moreover, as observed in cardiac mitochondria, the functional association of mitoBK $\mathrm{Ca}_{\mathrm{C}}$ with regulatory subunits $\beta 1$ broadens the spectrum of molecular targets suitable for the development of new and more directed therapies. Targeting the pore forming BKCa channel a-subunit with current and novel drugs needs to overcome the broad localization of the channel in brain cells. Considering that BKCa is expressed ubiquitously in brain cells it is essential to establish the differential and perhaps localized expression of BKCa channels and/or its regulatory subunits ( $\beta 1-4 ; \gamma 1-4)$ in oligodendrocytes. This would allow designing a more specific therapy alternative to immunosuppressive agents.

In summary, the review presented by Rupnik and coworkers represents a good collection of most recent information in the field of oligodendrocytes and the pathologies associated with demyelination, highlighting a possible role of the BKCa channel in preventing $\mathrm{Ca}^{2+}$ overload and 
reducing excitotoxic stress.

Our main suggestion would be to include a comment on the importance of the expression and association with BKCa-regulatory subunits and their possible use as novel targets for future therapies.

\section{References}

1. Hursh J: CONDUCTION VELOCITY AND DIAMETER OF NERVE FIBERS. American Journal of Physiology-Legacy Content. 1939; 127 (1): 131-139 Publisher Full Text

2. Waxman S, Swadlow H: The conduction properties of axons in central white matter. Progress in Neurobiology. 1977; 8: 297-324 Publisher Full Text

3. Waxman S, Sims T: Specificity in central myelination: evidence for local regulation of myelin thickness. Brain Research. 1984; 292 (1): 179-185 Publisher Full Text

4. Singh H, Lu R, Bopassa JC, Meredith AL, et al.: MitoBK(Ca) is encoded by the Kcnma1 gene, and a splicing sequence defines its mitochondrial location.Proc Natl Acad Sci U S A. 2013; 110 (26): 1083641 PubMed Abstract | Publisher Full Text

5. Balderas E, Torres NS, Rosa-Garrido M, Chaudhuri D, et al.: MitoBKCa channel is functionally associated with its regulatory $\beta 1$ subunit in cardiac mitochondria.J Physiol. 597 (15): 3817-3832 PubMed Abstract | Publisher Full Text

Is the topic of the review discussed comprehensively in the context of the current literature?

Yes

Are all factual statements correct and adequately supported by citations? Yes

Is the review written in accessible language?

Yes

Are the conclusions drawn appropriate in the context of the current research literature? Yes

Competing Interests: No competing interests were disclosed.

Reviewer Expertise: MaxiK, BK, mitochondrial ion channels, cardiac disorders, cardiovascular disease, vascular tone, immunotherapy, Ca2+ handling, ROS, cellular volume, cell death.

We confirm that we have read this submission and believe that we have an appropriate level of expertise to confirm that it is of an acceptable scientific standard.

Author Response 13 Oct 2021

David Selwood, University College London, London, UK

Response to Enrique Balderas-Angeles, and Veronica Loyo-Celis,

We thank the reviewers for their careful reading of the manuscript and useful comments 
and respond below. A new paragraph expressing some of these points will be added to the final manuscript.

Based on the reviewed evidence, there is an association of BK channel subunits with disease. BK channel activation is neuroprotective in animal models of spinal cord injury, ischaemia, and excitotoxic stress $(50,113,115,125)$, which share some pathological similarities with MS. This is confirmed by allele knockout or blockage with the antagonist's iberiotoxin and/ or paxilline that exacerbated injury $(113,115)$. The agonist isopimaric acid targeted the a subunit to improve motor function in rats with spinal cord injury (50). Similarly, NS1619 activated subunit a1 to effectively increase neuroprotection in rat and mouse cortex when used with leptin (115). Certain subunits may only be activated and therefore effectively targeted in the presence of cellular injury or excitotoxic conditions $(114,125)$, a quality which could arguably improve the specificity of an agent to injured tissue. However, these studies focused on neuron expression of BK channels and axon rather than oligodendrocyte integrity as an outcome. In clinical trials, BMS-204352 activates KCNMA1 also activates another potassium channel KCNQ. This was trialed as a safer neuroprotective agent to reduce intracellular $\mathrm{Ca}^{2+}$ levels in acute ischaemic stroke but did not significantly improve the outcome in this study (128). Andolast has been shown to significantly improve asthma symptoms compared to placebo, but its subunit targets have not yet been investigated (129). The anti-glaucoma agent unoprostone isopropyl activated iberiotoxin resistant BK channels, therefore likely successfully targeted the $\beta 2$, or $\beta 3$, subunits (130). The $\beta$ regulatory subunit is generally quite tissue-specific and therefore arguably a better target for an agonist than the $\alpha$ - subunit (121). In the CNS, KCNMB4 and KCNMB2 are the main regulatory subunits expressed (131). VSN16R, which is thought to target preferentially the $\beta 4$ subunit, has shown promise in reducing spasticity at higher doses with few side effects $(131,132)$. Notably, KCNMB4 is expressed in human mature oligodendrocytes (figure 3 ) and is possibly more abundant in chronic inactive MS lesions (117). Evidence is needed to ascertain whether an agonist to KCNMB4, or to another regulatory subunit, changes outcome in MS pathogenesis by targeting oligodendrocytes and by preserving myelin. Recently Fragile $X$ syndrome the major genetic cause of intellectual disability has been shown to have a demyelinating component. BK channel activation (specifically alpha1beta4) has been shown to restore both electrophysiological and behavioural functions in experimental Fragile X. A clinical evaluation should examine if remyelination is a component of the response to BK activator therapy.

Competing Interests: No competing interests were disclosed. 
The benefits of publishing with F1000Research:

- Your article is published within days, with no editorial bias

- You can publish traditional articles, null/negative results, case reports, data notes and more

- The peer review process is transparent and collaborative

- Your article is indexed in PubMed after passing peer review

- Dedicated customer support at every stage

For pre-submission enquiries, contact research@f1000.com 